\title{
Antigenic Targets of Patient and Maternal Autoantibodies in Autism Spectrum Disorder
}

\author{
Rut Mazón-Cabrera ${ }^{\dagger}$, Patrick Vandormael $^{\dagger}$ and Veerle Somers* \\ Biomedical Research Institute, Faculty of Medicine and Life Science, Hasselt University, Diepenbeek, Belgium
}

OPEN ACCESS

Edited by:

Fabienne Brilot,

University of Sydney, Australia

Reviewed by:

Enrico Castroflorio

Medical Research Council Harwell

(MRC), United Kingdom

Anna Fogdell-Hahn,

Karolinska Institute (KI), Sweden

${ }^{*}$ Correspondence:

Veerle Somers

veerle.somers@uhasselt.be

tThese authors have contributed equally to this work

Specialty section: This article was submitted to

Multiple Sclerosis and

Neuroimmunology,

a section of the journal

Frontiers in Immunology

Received: 08 April 2019

Accepted: 13 June 2019

Published: 19 July 2019

Citation:

Mazón-Cabrera R, Vandormael $P$ and Somers V (2019) Antigenic Targets of Patient and Maternal Autoantibodies in Autism Spectrum Disorder.

Front. Immunol. 10:1474. doi: 10.3389/fimmu.2019.01474
Autism spectrum disorder (ASD) is a neurodevelopmental disorder whose behavioral symptoms become apparent in early childhood. The underlying pathophysiological mechanisms are only partially understood and the clinical manifestations are heterogeneous in nature, which poses a major challenge for diagnosis, prognosis and intervention. In the last years, an important role of a dysregulated immune system in ASD has emerged, but the mechanisms connecting this to a disruption of brain development are still largely unknown. Although ASD is not considered as a typical autoimmune disease, self-reactive antibodies or autoantibodies against a wide variety of targets have been found in a subset of ASD patients. In addition, autoantibodies reactive to fetal brain proteins have also been described in the prenatal stage of neurodevelopment, where they can be transferred from the mother to the fetus by transplacental transport. In this review, we give an extensive overview of the antibodies described in ASD according to their target antigens, their different origins, and timing of exposure during neurodevelopment.

Keywords: autism, immunoglobulins, brain antigens, neurodevelopement, placental transfer

\section{INTRODUCTION}

Autism spectrum disorder (ASD) is a complex and highly heterogeneous neurodevelopmental disorder characterized by persistent deficits in social communication and social interaction (1). The patients also show restricted and repetitive patterns of behavior, interests and activities. Together with these symptoms, various comorbidities can occur, such as intellectual and language impairment, catatonia, epileptic seizures or attention-deficit/hyperactivity disorder (ADHD). These deficits can cause difficulties for the patient to understand, maintain or develop relationships, creating a barrier to their integration in social life.

ASD has become one of the most common neurodevelopmental disorders. The prevalence of ASD among 8-year-old children in the United States has more than doubled since 2000, increasing from 1 in 150 to 1 out of 59 children (2), and varies by sex, race/ethnicity and geographic area. It is four times higher among males than females and most common in non-Hispanic white children.

The diagnosis of ASD, usually made in early childhood, is based on observation of the atypical behaviors using questionnaires such as the Autistic Diagnostic Observation Schedule (ADOS) or Autism Diagnostic Interview-Revised (ADI-R). In each patient, the symptoms can have different manifestations caused by multiple etiologies, sub-types and developmental trajectories, often in combination with the different comorbidities, creating a complex condition (3). 
ASD is considered a polygenic hereditary disorder, whose genetic component mostly comprises of common variant singlenucleotide polymorphisms (SNP) and copy number variations (CNV) which can occur both in coding and non-coding regions (4). Moreover, the presence of autistic behaviors in other monogenic disorders such as Angelman syndrome and Fragile X syndrome only shows part of the complexity of this developmental disorder (5). Besides a genetic predisposition, ASD is also strongly influenced by environmental factors, which mostly play their specific roles before, during and after pregnancy (6). Factors as diverse as parental age, prematurity, pollution or geographic area have been found to contribute to increased risk of ASD (2, 7-9).

An overarching understanding of the etiology of the disorder is still lacking, but many areas and processes in the brain have been implicated. Disturbances in activation and regulation of the posterior insula, limbic system or the cortico-striato-thalamocortical circuit, contribute to the picture of a complex disease, not restricted to a single anatomical location (10-12). At the cellular level, alterations in synaptogenesis, synaptic plasticity and pruning, add another dimension of complexity (13-15).

In the last decade, an important role of the immune system has been described in the development of ASD. The activation of microglia, the resident immune cells of the brain, and increased levels of pro-inflammatory cytokines in brain tissue, cerebrospinal fluid and blood give evidence for the presence of ongoing neuroinflammation in brains of some ASD patients (16-19). Moreover, in utero exposure to an inflammatory environment during pregnancy caused by maternal autoimmune disease or maternal immune activation by infections, is sufficient to impart lifelong neuropathology and altered behaviors in offspring $(20,21)$.

Although ASD and other neurodevelopmental disorders are not typically considered as autoimmune diseases, autoantibodies, or antibodies that bind to self-antigens, have been detected in the sera of patients with ASD, ADHD, bipolar affective disorder and schizophrenia (22). Autoantibodies against known targets have been linked to the development of behavioral symptoms in these disorders, for example anti-dopamine transporter autoantibodies have been related with severity and recovery in ADHD, antibodies against myelin basic protein (MBP) have higher titers in patients with negative symptoms in schizophrenia or N-methyl-D-aspartate receptor (anti-NMDAR) and glutamic acid decarboxylase (anti-GAD) antibodies have been associated with acute maniac episodes in bipolar disorder (23-25). The beststudied example are autoantibodies directed against the NMDAR in a condition known as anti-NMDAR encephalitis, characterized by the development of psychosis, cognitive problems and seizures. The pathogenic role of anti-NMDAR autoantibodies in this disorder has been demonstrated in cultured neurons and in animal models (26-28). Moreover, patients have even been shown to respond to immunotherapy (29).

Besides the formation of autoreactive antibodies in ASD patients themselves, such antibodies have also been described in the blood of mothers whose child will develop ASD (Figure 1) (30, 31). These maternal autoantibodies can be transferred from the mother to the child during pregnancy via transplacental transport and might play an etiological role in ASD as they can pass the immature fetal blood-brain barrier (BBB) which is actively changing and semi-permeable during neurodevelopment $(32,33)$.

In this review, we explore the current evidence of antibodies detected in ASD patients and in mothers of ASD patients, their possible role as biomarkers to support the disease diagnosis and their contribution in the understanding of disease mechanisms.

\section{AUTOANTIBODIES IN ASD PATIENTS}

Autoantibodies in an ASD patient were first described by Todd et al. (31) in a study on hyperserotonemia. Antibodies in the blood and cerebrospinal fluid (CSF) of an ASD patient could block binding of radioactive serotonin to a human cortical brain homogenate. Although the presence of these autoantibodies was not supported by follow-up studies $(34,35)$, the idea that a subset of ASD patients may have antibodies against specific selfantigens in the brain started to gather much interest. Since then, autoantibodies in ASD patients have been mostly studied by looking at known, mostly brain-related autoantigens which have also been described in other autoimmune conditions (described below and in Table 1). Whether these specific autoantibodies can cross the $\mathrm{BBB}$, bind to their antigens in the brain and contribute to disease worsening, has not been demonstrated experimentally so far. Nonetheless, an increased general permeability of the $\mathrm{BBB}$ has been described for several psychiatric disorders, including ASD [reviewed in Kealy et al. (52)] which could provide a mechanism that would allow these autoantibodies to reach the brain. Moreover, most of the autoantibody targets described in ASD patients are localized intracellularly. It has long been assumed that large biomolecules such as antibodies cannot traverse the plasma membrane. However, for some anti-DNA antibodies in systemic lupus erythematosus (SLE) patients, membrane translocation and nuclear targeting has been demonstrated (53). Still, for the ASD-related autoantibodies described below, such mechanisms have not been investigated.

\section{Protein Targets} Myelin Basic Protein (MBP)

Myelin basic protein (MBP) is, together with the proteolipid protein (PLP), the most abundant protein in the myelin membrane (54). It is present on the cytoplasmic side of the membrane in oligodendrocytes of the central nervous system (CNS) and peripheral nervous system (PNS) (55). Its main function is structural, participating in membrane stabilization required for the formation of the myelin sheath, which insulates axons and allows saltatory action potential transmission (56). During brain development, myelination starts in the last weeks of the third trimester of pregnancy, and continues in adult life (57). Myelin integrity is essential for proper cognition, as damage in sheath formation can have severe consequences in the integrity of the white matter networks (58). Alterations in white matter development have been associated with autism manifestations, making MBP a highly interesting protein in the understanding of this effect $(10,59)$. Moreover, MBP damage can lead to induction 


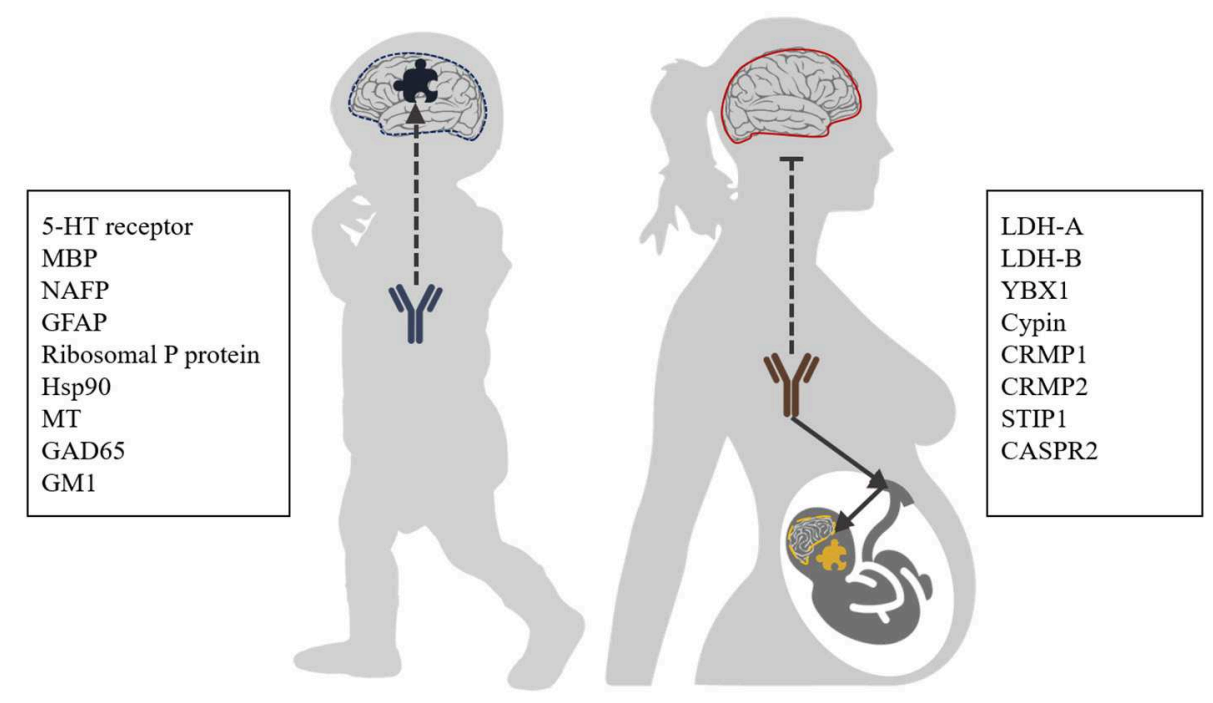

FIGURE 1 | Autoantibody targets in ASD. Autoantibodies with reactivity to brain antigens are generated in a subpopulation of ASD patients. Furthermore, the process of transplacental transport of antibodies, which provides infants with passive immunity, can also transfer antibodies which are reactive against fetal brain antigens. It is generally assumed that the BBB of healthy mothers is intact and impermeable to (auto)antibodies, while for ASD patients increased BBB permeability has been described. 5-HT receptor, 5-hydroxytryptamine receptor; NAFP, Neuron-axon filament protein; GFAP, Glial fibrillary acidic protein; MBP, Myelin Basic Protein; GM1, Ganglioside M1; GAD65, Glutamic acid decarboxylase; Hsp90, Heat shock protein 90; MT, Metallothionein; LDH-A/B, Lactate dehydrogenase A and B; YBX1, Y-box-binding protein 1; Cypin, Cytosolic PSD-95 interactor; CRMP1, Collapsin response mediator proteins 1; CRMP2, Collapsin response mediator proteins 2; STIP1, Stress-induced phosphoprotein 1; and CASPR2, Contactin-associated protein-like 2.

of inflammatory and chemotactic mediators which are able to alter the permeability of the BBB (60).

Based on the first descriptions of autoantibodies and abnormal immune function in autistic children $(31,61,62)$, Sing et al. (36) investigated the presence of immunoglobulin $\mathrm{G}$ ( $\mathrm{IgG}$ ) antibodies against MBP in ASD. MBP autoantibodies had already been described in the CSF of patients with multiple sclerosis (MS) (63). This first study compared a cohort of autistic children under 11 years of age, with age-matched normal children, children with idiopathic mental retardation and children with Down's syndrome (36). MBP-reactive antibodies were found using Western blot in 58\% of ASD children, while reactivities in the different control populations were much lower, ranging between 0 and 22\% (Table 1). In several follow-up studies, similar or even higher IgG reactivities were reported in autistic children using enzyme-linked immunosorbent assays (ELISA) against MBP (38-40). On the other hand, a study by Libbey et al. (37) could not replicate the presence of these anti-MBP antibodies.

Besides anti-MBP antibodies of the IgG isotype, IgA and IgM antibodies against MBP have also been reported in ASD patients (38, 40). Moreover, autoantibodies of all isotypes were also found against myelin-associated glycoprotein (MAG) and myelin oligodendrocyte glycoprotein (MOG), showing the diversity of the immune reactivity against key myelin proteins in ASD patients. Therefore, these autoantibodies might be informative on the underlying processes of autoimmunity in ASD patients.

However, since anti-MBP antibodies have already been described in several other diseases such as multiple sclerosis,
Parkinson's disease, rheumatoid arthritis or schizophrenia (24, $58,60,64,65)$, it seems unlikely that they would be useful as specific biomarkers for the diagnosis of ASD. Autoantibodies against myelin proteins might still have prognostic value for ASD patients, since serum levels of anti-MBP and anti-MAG antibodies were shown to be increased in severe autism patients compared to patients with mild or moderate disease severity (66).

The reported studies on autoantibodies against MBP in ASD children all have used small patient and control cohorts. Therefore, studies in multiple, independent large cohorts are required using similar detection assays to settle the reported differences in anti-MBP reactivity and to confirm a possible link with disease severity.

\section{Neurofilament Protein}

Neurofilaments are a class of intermediate filaments, which are part of the neural cytoskeleton, especially in axons of asymmetric, myelinated neurons involved in nerve conduction (67). They are composed of a triplet of proteins with different molecular weights (neurofilament light, $68 \mathrm{kDa}$; middle, $160 \mathrm{kDa}$ and heavy, $200 \mathrm{kDa}$ ) (67). Of these filament proteins, the neurofilament heavy protein (NF-H), also called neuron-axon filament protein (NAFP), is considered as a stable marker for neuron-axon filaments. It has an important role in the development of axons and the transport of vesicles via binding of kinesins, dynein complexes and kinases (68-71). Neurofilament subunit variants have been reported in the development of motor disorders and axonal neuropathies such as amyotrophic lateral sclerosis and 
TABLE 1 | Overview of ASD patient autoantibodies.

\begin{tabular}{|c|c|c|c|c|c|c|c|c|c|}
\hline \multicolumn{10}{|c|}{ Autoantibodies in patients } \\
\hline Antibody target & Isotype & MW (kDa) & $\begin{array}{l}\text { Protein } \\
\text { origin }\end{array}$ & Methods & Diagnosis & Sensitivity ${ }^{a}$ & Specificity ${ }^{b}$ & Cohort $^{c}$ & References \\
\hline \multirow[t]{2}{*}{ Serotonin $(5-H T)$ receptor } & $\lg G$ & NR & Human & Equilibrium saturation & DSM-III & NR & NR & Case study & (31) \\
\hline & $\lg G$ & & Human & Ligand binding & DSM-III & NR & NR & $3-19$ years & (35) \\
\hline \multirow[t]{5}{*}{ Myelin basic protein (MBP) } & $\lg G$ & $14-21$ & Rabbit & Western blot & DSM-III & $58 \%(19 / 33)$ & $\begin{array}{l}\text { MR } 85 \%(3 / 20) \\
\text { TD } 78 \%(4 / 18) \\
\text { A } 97 \%(1 / 38) \\
\text { DS } 100 \%(0 / 12)\end{array}$ & $\begin{array}{l}\leq 10 \text { years, } \\
\text { Adults } 20-40 \\
\text { years }\end{array}$ & (36) \\
\hline & $\lg G$ & & Bovine & ELISAMestern blot & $\begin{array}{l}\text { DSM- } \\
\text { IV/ADOS/ADI-R }\end{array}$ & NR & NR & $2-10$ years & (37) \\
\hline & $\lg G / \lg M$ & & NR & ELISA & DSM-IV & NR & NR & $2-9$ years & (38) \\
\hline & $\lg G$ & & Human & ELISA & DSM-IV & $80 \%(40 / 50)$ & TD 95\% (1.5/30) & 5-12 years & (39) \\
\hline & $\lg G / \lg M / \lg A$ & & NR & ELISA & DSM-III & NR & NR & 3-12 years & (40) \\
\hline $\begin{array}{l}\text { Neuron-axon filament } \\
\text { protein (NAFP) }\end{array}$ & $\lg G$ & 200 & Bovine & Western blot & DSM-III & $54.7 \%(29 / 53)$ & $\begin{array}{l}\text { MR } 66.6 \%(8 / 24) \\
\text { TD } 72.4 \%(16 / 58)\end{array}$ & $\begin{array}{l}4-48 \text { years }(90 \% \\
\text { younger than } 10 \\
\text { years) }\end{array}$ & (41) \\
\hline $\begin{array}{l}\text { Glial fibrillary acidic protein } \\
\text { (GFAP) }\end{array}$ & $\lg G$ & 50 & Bovine & Western blot & DSM-III & $32 \%(17 / 53)$ & $\begin{array}{l}\text { MR } 79.2 \%(5 / 24) \\
\text { TD } 91.4 \%(5 / 58)\end{array}$ & $\begin{array}{l}4-48 \text { years }(90 \% \\
\text { younger than } 10 \\
\text { years) }\end{array}$ & (41) \\
\hline Ribosomal P protein & $\lg G / \lg M$ & $17-38$ & Bovine & ELISA & DSM-IV/CARS & $44.3 \%(31 / 70)$ & TD 95\% (2.5/48) & $4-12$ years & (42) \\
\hline $\begin{array}{l}\text { Heat shock protein } 90 \\
\text { (Hsp90) }\end{array}$ & $\lg G$ & 90 & $\begin{array}{l}\text { Human cell } \\
\text { line }\end{array}$ & ELISA & NR & $19 \%(4 / 21)$ & $\begin{array}{l}\text { HC 100\% (0/61) } \\
\text { AD 100\% (0/35) }\end{array}$ & NR & (43) \\
\hline Metallothionein (MT) & $\lg G$ & $6-14$ & Human & ELISA & NR & $32 \%(13 / 41)$ & TD 88\% (4/33) & $2-16$ years & (44) \\
\hline $\begin{array}{l}\text { Glutamic acid } \\
\text { decarboxylase } 65 \text { (GAD65) }\end{array}$ & $\lg G$ & 65 & NR & ELISA & DSM-IV & $15 \%(3 / 20)$ & $\begin{array}{l}\text { ADHD 73\% (4/15) } \\
\text { TD 100\% (0/14) }\end{array}$ & $9-11$ years & (45) \\
\hline \multirow[t]{2}{*}{ Ganglioside M1 } & NR & 1.6 & Human & ELISA & DSM-IV & $74 \%(40 / 54)$ & TD 95\% (2.7/54) & $4-11$ years & (46) \\
\hline & NR & & Human & ELISA & $\begin{array}{l}\text { DSM-V/ADI- } \\
\text { R/ADOS/CARS/AB }\end{array}$ & $C^{37.8 \%(31 / 82)}$ & TD 78.3\% (13/60) & $2-5$ years & (47) \\
\hline $\begin{array}{l}\text { Double strand DNA } \\
\text { (ds-DNA) }\end{array}$ & $\lg G$ & NR & Human & ELISA & DSM-IV & $34 \%(34 / 100)$ & TD 98\% (2/100) & 4-11 years & (48) \\
\hline Nucleosome & $\lg G$ & NR & Human & ELISA & DSM-IV & $46.7 \%(28 / 60)$ & TD 95\% & $3-12$ years & (49) \\
\hline \multirow[t]{3}{*}{ Nuclear targets (ANA) } & $\lg G$ & NA & Human & Immunofluorescence & $\begin{array}{l}\text { Based on clinical } \\
\text { history }\end{array}$ & $27 \%(3 / 11)$ & LKSV $81.8 \%(2 / 11)$ & $2-6$ years & (50) \\
\hline & NR & NA & NR & $\begin{array}{l}\text { Indirect } \\
\text { Immunofluorescence }\end{array}$ & DSM-IV & $20 \%(16 / 80)$ & OND 90\% (2/20) & $3-12$ years & (51) \\
\hline & NR & NA & NR & $\begin{array}{l}\text { Indirect } \\
\text { Immunofluorescence }\end{array}$ & DSM-IV & $25 \%(25 / 100)$ & $\mathrm{NNI} / \mathrm{HC} 100 \%(0 / 51)$ & $4-11$ years & (48) \\
\hline
\end{tabular}

${ }^{a}$ Sensitivity is the percentage of seropositive ASD patients, the amount of seropositive patients over the total tested patient cohort is indicated between brackets. ${ }^{b}$ Specificity is the percentage of seronegativity in the control populations (TD, MR, A, DS, OND, NNI, HC, AD, ADHD, LKSV), the amount of seropositive controls over the total amount of each control cohort is indicated between brackets. ${ }^{\circ}$ Age range of study population; NA, not applicable; NR, not reported; MR, mental retardation; TD, typically developing; A, adults; DS, Down syndrome; OND, other neurological disorders; NNI, non-neurological illnesses; HC, healthy children; ADHD, attention-deficit/hyperactivity disorder; LKSV, Landau-Kleffner syndrome variant; AD, autoimmune disorder; DSM-III, Diagnostic and statistical manual of mental disorders third edition; DSM-IV, Diagnostic and statistical manual of mental disorders fourth edition; ADOS, Autistic Diagnostic Observation Schedule; ADI-R, Autism Diagnostic Interview-Revised; CARS, Chilhood autism rating scale; ABC, Autism behavior checklist. 
Charcot-Marie-Tooth disease $(72,73)$. Autoantibodies against $\mathrm{NF}-\mathrm{H}$ have been described in normal aging, but also in degenerative disorders such as Alzheimer's disease, multiple sclerosis and prion diseases (74-77). In ASD, IgG antibodies reactive against bovine NF-H (NAFP) were found using Western blot in nearly $55 \%$ of the patients studied (Table 1) (41). However, the percentage of seronegativity in control populations (i.e., specificity) of these autoantibodies is lower than $80 \%$ in controls with a typical development and idiopathic mental retardation. A study by Vojdani confirmed the increased presence of IgG, IgM, and IgA autoantibodies against NAFP in autistic patients (40).

\section{Glial Fibrillary Acidic Protein (GFAP)}

The glial fibrillary acidic protein (GFAP) is a class III intermediate filament cytoskeletal protein. This protein allows the distinction between astrocytes and other glial cells, and is a common astroglial marker in the CNS. Furthermore, it is present in non-myelinating Schwann cells in the PNS and in enteric glial cells (78). In case of acute brain injury, astrocytes become activated, strongly upregulate GFAP expression and increase in size and number, a state called astrogliosis (79). After stroke, traumatic brain injury and spinal cord injury, GFAP, and GFAP breakdown products have been found in CSF and serum (80). These breakdown products trigger an autoantibody response against GFAP in a large subset of patients $(81,82)$. Elevated GFAP levels have also been described in brain tissue, CSF and serum of ASD patients (83-86), as is the associated autoimmune reactivity. IgG antibodies against GFAP were detected using Western blot in $32 \%$ of ASD patients with a specificity of $91 \%$ in typically developing subjects, but only $79 \%$ in idiopathic mental retarded subjects (Table 1) (41). However, in a small study by Kirkman et al. (87), the average titer of anti-GFAP antibodies in autistic patients was not found to be significantly higher than in controls, raising questions about the role of this antibodymediated response in this developmental disorder.

\section{Ribosomal P Proteins}

The ribosomal $\mathrm{P}$ proteins are three specific ribosomal proteins located in the large ribosomal subunit (60S). These proteins, $\mathrm{P} 0, \mathrm{P} 1$, and $\mathrm{P} 2$, are present in the nucleus and cytoplasm, and are involved in the binding of ribosomal RNA, assembly of the 60 S subunit and protein translation (88-90). Autoantibodies reactive against these $\mathrm{P}$ proteins are present in nearly one-third of SLE patients and have also been detected in patients with autoimmune hepatitis (91-93). Neuropsychiatric manifestations are some of the most serious complications in SLE, and the occurrence of psychosis in SLE patients has been associated with the presence of anti-ribosomal P antibodies (94). These autoantibodies seem to cross-react with a neuronal integral membrane protein called neuronal surface P antigen (NSPA) (95) and administration of anti-ribosomal $\mathrm{P}$ antibodies into murine brains induced neuronal apoptosis and disturbance of the normal functioning of hippocampus and cortex $(96,97)$, while memory impairment was observed when administered systemically and BBB damage was induced (96). The pathogenicity of these antibodies in other disorders remains unknown, however, in two small studies, elevated anti-ribosomal $\mathrm{P}$ protein antibodies were also found using ELISA in 44 to $58 \%$ of autistic children and in $5 \%$ of the healthy control groups (Table 1) $(42,98)$. Moreover, the presence of these antibodies in autistic children was related with the levels of the neuropeptide Neurokinin A (42) and with the levels of lead in the blood (98).

\section{Heat Shock Protein 90 (Hsp90)}

Heat shock protein 90 (Hsp90) is a chaperone involved in assisting the proper folding of proteins and their stabilization (99). Immunoglobulins against this molecular chaperone were found at significantly higher levels in autistic patients than in typically developing controls (43). At the cutoff used, 19\% of ASD patients were seropositive for Hsp90 autoantibodies and none of the healthy subjects or controls with autoimmune disorders (Table 1). These reactivities have only been reported for a small study population and have not been replicated in independent studies so far. Therefore, the role of these autoantibodies in autoimmune and other diseases is still unclear.

\section{Metallothionein (MT)}

Metallothioneins (MT) are intracellular proteins involved in the homeostasis of essential metals and the detoxification of heavy metals (100). The consequences of environmental exposure to noxious agents and their exact role in the pathology of ASD are still under investigation, but it is known that exposure to pollution and heavy metals is causally implicated in changes of fetal neurodevelopment that are related with autism $(8,101$, 102). The presence of anti-MT antibodies has been described in metal-induced diseases such as occupational heavy metal exposure and metal allergy $(103,104)$. Furthermore, one in four autistic children showed a higher MT concentration in the serum and one third of ASD patients showed increased levels of autoantibodies against MT (Table 1) (105). These findings might indicate immune abnormalities related to levels of metal exposure in ASD patients.

\section{Glutamic Acid Decarboxylase (GAD65)}

GAD65 is the enzyme responsible for the conversion of glutamate to GABA, an inhibitory neurotransmitter in the CNS (106). Anti-GAD65 antibodies have typically been associated with autoimmune diseases not related with the nervous system such as type 1 diabetes, however they have also been reported in CNS disorders such as encephalitis, epilepsy and cerebellar ataxia, where they could even have a pathological role (106110). The role of GAD65 in neurotransmitter production and the relationship with seizure episodes made it an interesting target in brain disorders with excitation/inhibition imbalance such as autism (106). In a small study using 20 patients, the presence of anti-GAD65 antibodies measured using ELISA was reported in $15 \%$ of the autism cases, $27 \%$ of ADHD patients and in none of the controls (Table 1) (45). Despite the size of the study, an initial indication of a possible relation between these autoantibodies and autism was made. In the future, it might be interesting to test the presence of anti-GAD65 antibodies in the subpopulation of ASD patients that present ataxia-related problems or seizures. 


\section{Non-protein Targets Ganglioside M1 (GM1)}

Ganglioside M1 is a glycosphingolipid with one sialic acid residue that is present in the cell membrane (111). It is involved in neuronal plasticity and neurotrophin secretion during development, adulthood and aging (111, 112). AntiGM1 antibodies have been described in motor neuropathies, but also in neurodegenerative diseases such as GM1 gangliosidosis, multifocal motor neuropathy, dementia and Guillain-Barré syndrome (113-116). Two studies have reported increased levels of these antibodies in ASD patients using ELISA, however with widely different sensitivities, varying from 74 to $38 \%$, and corresponding specificities of 95 and 78\%, respectively (Table 1) $(46,47)$. Moreover, in the study by Mostafa et al. (46), a significant correlation with disease severity was found, whereas this could not be confirmed in another study (47). Nevertheless, it seems that anti-GM1 antibodies have been associated with ASD, but their specific role remains to be elucidated.

\section{Nuclear Antigens}

Antinuclear antibodies (ANAs) are immunoglobulins that react against nuclear components, mostly double stranded DNA (dsDNA) and DNA-associated proteins. These antigens are not organ-specific and are ubiquitous in every cell. ANAs have been detected in cancer and premalignant diseases, but mostly in autoimmune disorders such as SLE (117119). Renal failure, nephritis and damage in the glomerular structures have been related to these antibodies (120-123). ANAs, anti-dsDNA and anti-nucleosome antibodies have also been described in autism patients (48-51). Immunoglobulins against general nuclear targets were found in up to a quarter of ASD patients using indirect immunofluorescence detection (Table 1) (48, 49, 51). These ANAs show a high specificity (over 96\%) in typically developing children. More specific measurements, using ELISA for anti-ds-DNA or antinucleosome antibodies, showed that, respectively 34 and $47 \%$ of ASD patients were seropositive for these ANAs $(48,49)$. The presence of antinuclear immunoglobulins has been reported to be increased in patients with severe autism, but also with abnormal electroencephalogram results and mental retardation, suggesting that even if these antibodies cannot be used as a diagnostic test, they might be symptom related $(50,51)$. In addition, the presence of these antibodies is related with a family history of autoimmunity, even more related to autoimmune diseases in female relatives (51). Between 29 and $48 \%$ of the ASD patients seropositive for anti-nuclear antibodies have an autoimmune background $(48,51)$. The presence of high titers of anti-nuclear antibodies in other autoimmune disorders reduces the chances of using ANAs patterns as a separate diagnostic tool in autism $(50,124)$.

\section{MATERNAL AUTOANTIBODIES}

After being born from the sterile environment of the womb, neonates are rapidly exposed to many different microbial and environmental antigens, while their immune system is still inexperienced. Therefore, during the first months of life, an important mechanism of protection is provided via passive immunization with antibodies, which are been transferred from the mother to the fetus during pregnancy [reviewed in Palmeira et al. (125)]. This occurs via binding to the neonatal Fc receptor (FcRn), which transports IgG subclasses 1, 3, and 4 across the placenta, during the second and third trimester of pregnancy.

In the nineties, around the same time the involvement of the immune system and the presence of autoantibodies in ASD patients were being elucidated, the relationship between aberrant maternal immune responses and autism in children was also being explored. The history of spontaneous abortions and disorders during pregnancy in mothers that later had a child with ASD, together with the suggestion of the presence of antipaternal antibodies in mothers with a complicated pregnancy record, led to the study of antibody reactivity of maternal plasma against targets in their children (126). In this context, Warren et al. detected increased complement-dependent cytotoxicity by maternal antibodies in $54 \%(6 / 11)$ of mothers of autistic children and in $10 \%(2 / 20)$ of mothers of normal children (126). Despite the small number of subjects, this study was the first indication of a possible correlation between maternal antibodies and the development of autism in their children. Binding of maternal antibodies to brain proteins was first described in a case study (30). Using serum from a mother of 2 children with different developmental disorders including autism, binding of autoantibodies to Purkinje cells and large neurons in murine cerebellum and brainstem was described. A direct functional role for these antibodies was also suggested, as passive transfer of serum of this mother in pregnant mice led to altered exploratory behavior in the pups (30).

In order to further understand this reactivity, several studies were performed to identify maternal antibodies and their antigenic targets (Table 2). In a study by Zimmerman, $45 \%(5 / 11)$ of mothers of autistic children showed reactivity against a pattern of 5 proteins between 15 and $37 \mathrm{kDa}$ of fetal rat brain using Western blot (130). This pattern was not observed in mothers of typically developing children or using postnatal and adult rat brain extracts. Using a bigger cohort of 100 mothers of children with autistic disorder and 100 controls, immunoreactivity using Western blot against a $36 \mathrm{kDa}$ human fetal brain protein was found in $10 \%$ of the mothers of ASD children (MASD) and only in $2 \%$ of the mothers with typically developing children (MTD) (128). A $36 \mathrm{kDa}$ and a $73 \mathrm{kDa}$ band were also identified using rodent embryonic brain tissue in $47-48 \%$ of MASD with a specificity of $69 \%$ in MTD. In addition, the group of Van de Water performed multiple analyses on maternal samples from the CHARGE study (Childhood Autism Risks from Genetics and the Environment), where mothers were sampled up till 5 years after delivery, but also on maternal mid-pregnancy serum samples from the EMA study (Early Markers for Autism) (131-133, 135, 136). Highly specific patterns of immunoreactivity toward rhesus macaque or human fetal brain extract were found in mothers of children with autism, where a $73 \mathrm{kDa}$ band was combined with either a 37 or a $39 \mathrm{kDa}$ band. Mass spectrometric analysis of immunoreactive spots from a fetal rhesus macaque brain protein extract, resulted in the identification of seven primary 


\begin{tabular}{|c|c|c|c|c|c|c|c|c|}
\hline \multicolumn{9}{|c|}{ Maternal autoantibodies } \\
\hline Antibody target & Isotype & MW (kDa) & Protein Origin & Methods & Sensitivity ${ }^{a}$ & Specificity ${ }^{b}$ & Serum/Plasma & References \\
\hline $\begin{array}{l}\text { Lactate dehydrogenase } \\
A \text { and } B(L D H)\end{array}$ & $\lg G$ & 37 & $\begin{array}{l}\text { Rhesus macaque brain } \\
\text { (152 days) }\end{array}$ & Western blot & $28 \%(68 / 246)$ & MTD 87\% (20/149) & Plasma & $(127)$ \\
\hline $\begin{array}{l}\text { Cytosolic PSD-95 } \\
\text { interactor (Cypin) }\end{array}$ & $\lg G$ & 44 & $\begin{array}{l}\text { Rhesus macaque brain } \\
\text { (152 days) }\end{array}$ & Western blot & $25 \%(62 / 246)$ & MTD 81\% (29/149) & Plasma & (127) \\
\hline $\begin{array}{l}\text { Stress-induced } \\
\text { phosphoprotein } 1 \\
\text { (STIP1) }\end{array}$ & $\lg G$ & 73 & $\begin{array}{l}\text { Rhesus macaque brain } \\
\text { (152 days) }\end{array}$ & Western blot & $59 \%(145 / 246)$ & MTD 64\% (53/149) & Plasma & (127) \\
\hline $\begin{array}{l}\text { Collapsin response } \\
\text { mediator proteins } 1 \\
\text { (CRMP1) }\end{array}$ & $\lg G$ & 70 & $\begin{array}{l}\text { Rhesus macaque brain } \\
\text { (152 days) }\end{array}$ & Western blot & $32 \%(78 / 246)$ & MTD 82\% (27/149) & Plasma & (127) \\
\hline $\begin{array}{l}\text { Collapsin response } \\
\text { mediator proteins } 2 \\
\text { (CRMP2) }\end{array}$ & $\lg G$ & 62 & $\begin{array}{l}\text { Rhesus macaque brain } \\
\text { (152 days) }\end{array}$ & Western blot & $18 \%(44 / 246)$ & MTD 93\% (11/149) & Plasma & (127) \\
\hline $\begin{array}{l}\text { Y-box-binding protein } \\
\text { (YBX1) }\end{array}$ & $\lg G$ & 39 & $\begin{array}{l}\text { Rhesus macaque brain } \\
\text { (152 days) }\end{array}$ & Western blot & $31 \%(78 / 246)$ & MTD 77\% (34/149) & Plasma & $(127)$ \\
\hline $\begin{array}{l}\text { LDH + STIP1 + } \\
\text { CRMP1 }\end{array}$ & $\lg G$ & $37+73$ & $\begin{array}{l}\text { Rhesus macaque brain } \\
\text { (152 days) }\end{array}$ & Western blot & $5 \%(13 / 246)$ & MTD 100\% (0/149) & Plasma & (127) \\
\hline $\begin{array}{l}\text { LDH + STIP1 + } \\
\text { CRMP1 + Cypin }\end{array}$ & $\lg G$ & NR & $\begin{array}{l}\text { Rhesus macaque brain } \\
\text { (152 days) }\end{array}$ & Western blot & $2 \%(5 / 246)$ & MTD 100\% (0/149) & Plasma & (127) \\
\hline $\begin{array}{l}\text { Specific combinations } \\
\text { of LDH, STIP1, } \\
\text { CRMP1, Cypin, } \\
\text { CRMP2, YBX1 }\end{array}$ & $\lg G$ & NR & $\begin{array}{l}\text { Rhesus macaque brain } \\
\text { (152 days) }\end{array}$ & Western blot & $23 \%(56 / 246)$ & MTD 99\% (2/149) & Plasma & $(127)$ \\
\hline Purkinje cells & $\lg G$ & NR & $\begin{array}{l}\text { Adult rat brain } \\
\text { P1 mouse brain }\end{array}$ & \multicolumn{2}{|c|}{ Immunohistochemistry Case study } & Case study & Serum & (30) \\
\hline NB-1 neuroblastoma & $\lg G$ & NR & Human cell line & \multicolumn{2}{|c|}{ Immunohistochemistry Case study } & Case study & Serum & (30) \\
\hline GFAP & $\lg G$ & & Human & Western blot & $10 \%(2 / 20)$ & MTD 85\% (3/20) & $\begin{array}{l}\text { Serum (years after } \\
\text { delivery) }\end{array}$ & (128) \\
\hline MBP & $\lg G$ & $18-20$ & Human & Western blot & $5 \%(1 / 20)$ & MTD 90\% (2/20) & $\begin{array}{l}\text { Serum (years after } \\
\text { delivery) }\end{array}$ & (128) \\
\hline Nuclear targets (ANA) & $\lg G$ & NR & Mouse (12 weeks) & \multicolumn{2}{|c|}{ Immunohistochemistry 24.5\% (251/1022) } & MTD 84.9\% (52/345) & Plasma & (129) \\
\hline \multirow[t]{5}{*}{ Fetal Brain proteins } & $\lg G$ & $\begin{array}{r}15-37 \\
>250\end{array}$ & Fetal rat brain & Western blot & $\begin{array}{l}45.4 \%(5 / 11) \\
54.5 \%(6 / 11)\end{array}$ & $\begin{array}{l}\text { MTD 100\% (0/10) } \\
\text { MTD 100\% (0/10) }\end{array}$ & Serum & (130) \\
\hline & $\lg G$ & 32 & Human (20-40 weeks) & Western blot & $3.6 \%(3 / 84)$ & $\begin{array}{l}\text { MTD 100\% (0/152) } \\
\text { MDD 95.8\% (2/48) }\end{array}$ & $\begin{array}{l}\text { Serum (15-19 weeks of } \\
\text { gestation) }\end{array}$ & (131) \\
\hline & $\lg G$ & 36 & Human (17-weeks) & Western blot & $10 \%(10 / 100)$ & MTD 98\% (2/100) & $\begin{array}{l}\text { Serum (years after } \\
\text { delivery) }\end{array}$ & (128) \\
\hline & $\lg G$ & 37 & Human (20-40 weeks) & Western blot & $26.2 \%(16 / 61)$ & $\begin{array}{l}\text { MTD } 91.9 \%(5 / 62) \\
\text { MDD } 97.5 \%(1 / 40)\end{array}$ & $\begin{array}{l}\text { Plasma ( } 2-5 \text { years after } \\
\text { delivery) }\end{array}$ & (132) \\
\hline & $\lg G$ & & $\begin{array}{l}\text { Rhesus macaque brain } \\
\text { (152 days) }\end{array}$ & Western blot & $6.6 \%(17 / 259)$ & MTD 93.9\% (11/180) & Plasma & $(132)$ \\
\hline
\end{tabular}




\begin{tabular}{|c|c|c|c|c|c|c|c|c|}
\hline \multicolumn{9}{|c|}{ Maternal autoantibodies } \\
\hline Antibody target & Isotype & MW (kDa) & Protein Origin & Methods & Sensitivity ${ }^{a}$ & Specificityb & Serum/Plasma & References \\
\hline & $\lg G$ & 39 & Human (20-40 weeks) & Western blot & $7.1 \%(11 / 84)$ & $\begin{array}{l}\text { MTD 98\% (3/152) } \\
\text { MDD 100\% (0/48) }\end{array}$ & $\begin{array}{l}\text { Serum (15-19 weeks of } \\
\text { gestation) }\end{array}$ & (131) \\
\hline & $\lg G$ & & Human (17-weeks) & Western blot & $14 \%(14 / 100)$ & MTD 85\% (15/100) & $\begin{array}{l}\text { Serum (years after } \\
\text { delivery) }\end{array}$ & (128) \\
\hline & $\lg G$ & & $\begin{array}{l}\text { Rhesus macaque brain } \\
\text { (152 days) }\end{array}$ & Western blot & $10.4 \%$ (27/ 259) & MTD 83.9\% (29/180) & Plasma & (132) \\
\hline & $\lg G$ & 60 & Human (20-40 weeks) & Western blot & $19 \%(16 / 84)$ & $\begin{array}{l}\text { MTD } 76.3 \%(36 / 152) \\
\text { MDD } 75 \%(12 / 48)\end{array}$ & $\begin{array}{l}\text { Serum (15-19 weeks of } \\
\text { gestation) }\end{array}$ & (131) \\
\hline & $\lg G$ & 61 & Human (17-weeks) & Western blot & $30 \%(30 / 100)$ & MTD 69\% (31/100) & $\begin{array}{l}\text { Serum (years after } \\
\text { delivery) }\end{array}$ & (128) \\
\hline & $\lg G$ & 73 & Human (20-40 weeks) & Western blot & $13.1 \%(11 / 84)$ & $\begin{array}{l}\text { MTD } 92.8 \%(11 / 152) \\
\text { MDD 95.8\% (2/48) }\end{array}$ & $\begin{array}{l}\text { Serum (15-19 weeks of } \\
\text { gestation) }\end{array}$ & (131) \\
\hline & $\lg G$ & & $\begin{array}{l}\text { Rhesus macaque brain } \\
\text { (152 days) }\end{array}$ & Western blot & $16.2 \%(42 / 259)$ & MTD $87.8 \%(22 / 180)$ & Plasma & (132) \\
\hline & $\lg G$ & $37+73$ & Human (20-40 weeks) & Western blot & $11.5 \%(7 / 61)$ & $\begin{array}{l}\text { MTD 100\% (0/62) } \\
\text { MDD 100\% (0/40) }\end{array}$ & $\begin{array}{l}\text { Plasma ( } 2-5 \text { years after } \\
\text { delivery) }\end{array}$ & (133) \\
\hline & $\lg G$ & & Monkey brain & Western blot & $9 \%(9 / 202)$ & MTD 100\% (0/163) & Plasma & (134) \\
\hline & $\lg G$ & & $\begin{array}{l}\text { Rhesus macaque brain } \\
\text { (152 days) }\end{array}$ & Western blot & $9.3 \%(24 / 259)$ & $100 \%(0 / 180)$ & Plasma & (132) \\
\hline & $\lg G$ & & $\begin{array}{l}\text { Rhesus macaque brain } \\
(49,100,152 \text { days })\end{array}$ & Western blot & $7 \%(10 / 143)$ & $\begin{array}{l}\text { MTD 100\% (0/121) } \\
\text { MDD 100\% (0/62) }\end{array}$ & Plasma & (135) \\
\hline & $\lg G$ & & Rhesus macaque & Western blot & $7.6 \%(10 / 131)$ & MTD 100\% (0/50) & Plasma & (136) \\
\hline & $\lg G$ & $39+73$ & Human (20-40 weeks) & Western blot & $3.6 \%(3 / 84)$ & $\begin{array}{l}\text { MTD 100\% (0/152) } \\
\text { MDD 95.8\% (2/48) }\end{array}$ & $\begin{array}{l}\text { Serum (15-19 weeks of } \\
\text { gestation) }\end{array}$ & (131) \\
\hline & $\lg G$ & & $\begin{array}{l}\text { Rhesus macaque brain } \\
\text { (152 days) }\end{array}$ & Western blot & $8.9 \%(23 / 259)$ & MTD 98.3\% (3/180) & Plasma & (132) \\
\hline & $\lg G$ & $60+73$ & Human (20-40 weeks) & Western blot & $6 \%(5 / 84)$ & $\begin{array}{l}\text { MTD 98\% (3/152) } \\
\text { MDD 97.9\% (1/48) }\end{array}$ & $\begin{array}{l}\text { Serum (15-19 weeks of } \\
\text { gestation) }\end{array}$ & (131) \\
\hline & $\lg G$ & NR & Mouse (12 weeks) & Immunohistochemistry & 10.7\% (260/2431) & MTD 97.4\% (17/653) & Plasma & (129) \\
\hline $\begin{array}{l}\text { Adult Brain cingulate } \\
\text { gyrus protein }\end{array}$ & $\lg G$ & $\begin{array}{c}91 \\
100 \\
129\end{array}$ & Human & Western blot & $\begin{array}{l}13 \%(13 / 100) \\
5 \%(5 / 100) \\
26 \%(26 / 100)\end{array}$ & $\begin{array}{l}\text { MTD } 80 \%(20 / 100) \\
\text { MTD 100\% (0/100) } \\
\text { MTD 79\% (21/100) }\end{array}$ & $\begin{array}{l}\text { Serum (years after } \\
\text { delivery) }\end{array}$ & (128) \\
\hline $\begin{array}{l}\text { Adult Brain cerebellum } \\
\text { protein }\end{array}$ & $\lg G$ & $\begin{array}{l}31 \\
100\end{array}$ & Human & Western blot & $\begin{array}{l}25 \%(25 / 100) \\
34 \%(34 / 100)\end{array}$ & $\begin{array}{l}\text { MTD 65\% (35/100) } \\
\text { MTD 70\% (30/100) }\end{array}$ & $\begin{array}{l}\text { Serum (years after } \\
\text { delivery) }\end{array}$ & (128) \\
\hline $\begin{array}{l}\text { Adult Brain caudate } \\
\text { protein }\end{array}$ & $\lg G$ & $\begin{array}{l}81 \\
155\end{array}$ & Human & Western blot & $\begin{array}{l}20 \%(20 / 100) \\
11 \%(11 / 100)\end{array}$ & $\begin{array}{l}\text { MTD 79\% (21/100) } \\
\text { MTD 98\% (2/100) }\end{array}$ & $\begin{array}{l}\text { Serum (years after } \\
\text { delivery) }\end{array}$ & (128) \\
\hline $\begin{array}{l}\text { Adult Brain frontal } \\
\text { cortex (BA9) }\end{array}$ & $\lg G$ & 63 & Human & Western blot & 39\% (39/100) & MTD 73\% (27/100) & $\begin{array}{l}\text { Serum (years after } \\
\text { delivery) }\end{array}$ & (128) \\
\hline
\end{tabular}




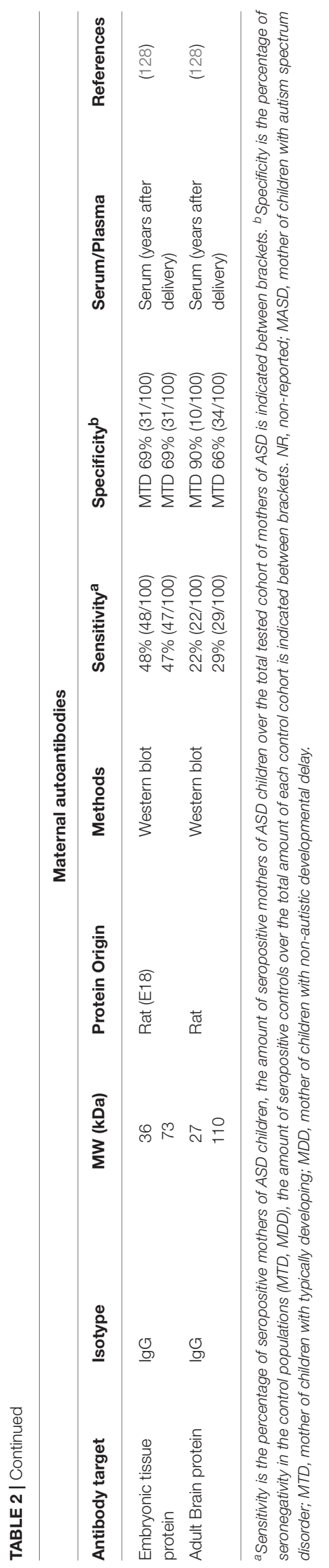

targets of maternal antibodies related with autism: lactate dehydrogenase $\mathrm{A}$ and $\mathrm{B}(\mathrm{LDH}-\mathrm{A} / \mathrm{B})(37 \mathrm{kDa})$, Y-box-binding protein 1 (YBX1) (39 kDa), Cytosolic PSD-95 interactor (Cypin) $(44 \mathrm{kDa})$, Collapsin response mediator protein 2 (CRMP2) $(62 \mathrm{kDa})$, Collapsin response mediator protein 1 (CRMP1) $(70 \mathrm{kDa})$, and Stress-induced phosphoprotein 1 (STIP1) (73 $\mathrm{kDa}$ ) (Table 2) (127). Individually, testing immunoreactivity against these targets using Western blot resulted in sensitivities ranging from 18 to $59 \%$ in mothers of ASD children, with specificities between 64 and $93 \%$ in mothers of typically developing children (Table 2). Combination of different panels, each consisting of immunoreactivity against specific combinations of two or more antigens of these seven targets, led to a large increase in specificity (99\%), while maintaining a relatively high sensitivity of $23 \%$ (56/246) (Table 2). Moreover, an increased impairment in stereotypical behavior was observed in children of mothers with LDH-, or combined LDH/STIP1- or LDH/STIP1/CRMP1 immunoreactivity.

The active contribution of these maternal autoantibodies in the development of autistic features in the offspring has been investigated in animal models using passive transfer of the total IgG fraction purified from mothers of ASD children or mothers of typically developing children. Pregnant mouse dams have been injected with purified $\operatorname{IgG}$ around the end of the second trimester of pregnancy, either with a single injection in the maternal periphery (137) or in the embryonic brain ventricles $(69,138)$, or by daily peripheral injections during the third trimester (139). Recently, a novel active immunization model has also been applied, where female mice were immunized before pregnancy with a mixture of immunogenic peptides from LDH-A/B, STIP1, and CRMP1, providing a more representative situation where mouse dams produce antibodies themselves during the entire pregnancy $(140,141)$. Mice exposed to these maternal autoantibodies during development showed increased cell division of radial glial cells in the subventricular zone, increased neuronal size in the cortex (142) and a reduction in the number of dendritic spines and of the dendritic arborization in the neurons of the infragranular layers of the adult cortex (138). This coincides with autism-related behavioral changes such as impaired motor and sensory development, hyperactivity, anxiety, inappropriate social interactions and repetitive and stereotypic behaviors $(69,137,139,141)$. While these maternal autoantibodies have been shown to reach high levels in the brains of the embryos, only a very low amount could be found in the brains of the dams $(137,139)$, probably due to differences in BBB permeability in embryonic and adult brains. Moreover, behavioral changes in the dams themselves have not been reported so far.

These studies do not directly pinpoint the involvement of a single autoantibody target in ASD development, but remain an important tool to experimentally demonstrate that autoantibody transfer during pregnancy can alter brain biology, resulting in autistic behaviors in the offspring. A detailed overview of the autoantibodies described in mothers of children with ASD is presented in Table 2. The biomarker potential, general function, expression and possible role during neurodevelopment of the 
most interesting autoantibody targets is discussed below in more detail.

\section{Lactate Dehydrogenase A and B (LDH-A and LDH-B)}

Antibodies to LDH-A and LDH-B were found in $28 \%$ of mothers of ASD children and 13\% of mothers of typically developing children (Table 2) (127). Lactate dehydrogenase $(\mathrm{LDH})$ is an oxidoreductase responsible for the reversible conversion of the glycolytic intermediate pyruvate to lactate. This leads to rapid energy production via fermentation of pyruvate, instead of fully metabolizing it to $\mathrm{CO}_{2}$ via aerobic respiration in the mitochondria. LDH is encoded by 3 different genes $L D H-A, B$ and $C$ that correspond to 3 different protein subunits, which can combine into homotetrameric or heterotetrameric isoenzymes (143). LDH-A and LDH-B are differentially expressed in different adult brain regions, with LDH-A showing a diffusely distributed expression pattern, with increased expression in the hippocampus and cortex, while LDH-B shows high expression in several brain structures such as the olfactory bulb and piriform cortex, several thalamic and hypothalamic nuclei, the granular, and Purkinje cell layers of the cerebellum and a laminar pattern in the neocortex (144). Isoenzymes which are preferentially composed of LDH-A or LDH-B have different metabolic functions, and the ratio between $\mathrm{A}$ and $\mathrm{B}$ is responsible for the balance between glycolysis and oxidative phosphorylation in different tissues (143).

Serum LDH activity has been found to be increased in ASD patients and appears to be related to the level of disease severity (145). Interestingly, increased levels of pyruvate and lactate, the metabolites which are interconverted by $\mathrm{LDH}$, are often used as a marker for mitochondrial dysfunction, as less pyruvate is metabolized through the tricarboxylic acid cycle in mitochondria [reviewed in Rossignol and Frye (146)]. Besides increased levels of pyruvate and lactate, several other lines of evidence, such as altered levels of other carbon metabolites and activity changes or mutations in enzymes involved in carbon metabolism, indicate a broader mitochondrial dysfunction in a subset of autism patients $(147,148)$. As neurons are highly energy dependent cells, dysregulation of energy metabolism can implicate changes in their main functions and structures. Still, the exact role of mitochondrial dysfunction and carbon metabolism in ASD pathology remains poorly understood.

\section{Y-Box-Binding Protein 1 (YBX1)}

Antibodies to YBX1 were found in $31 \%$ of mothers of ASD children and $23 \%$ of mothers of typically developing children (Table 2) (127). Specific combinations of antibody reactivity to YBX1 and LHD or CRMP2 were found in a smaller percentage of mothers of ASD children (2-5\%), but with much higher corresponding specificities (99-100\%). YBX1 encodes the Y-box-binding protein 1, also called nucleasesensitive element-binding protein 1 . This protein is involved in DNA and RNA-binding during mRNA processing, splicing, transcription and transcription regulation and is important for processes such as stress response, cell proliferation, and differentiation $(149,150)$. Furthermore, this protein is involved in differentiation of neuronal progenitors, maintenance of the stem cell status and malignant cell transformation (151). YBX1 has a general expression in most murine tissues, both during embryonic development and in adulthood (152). In the adult human brain, YBX1 is mainly located in neurons throughout the brain, while prenatally it is expressed in radial glia, neuroblasts and neurons (153). Homozygous knockout of YBX1 leads to embryonic lethality, with abnormalities in neural tube formation (154).

The role of YBX1 in ASD is still unknown, but it has a direct protein-protein interaction with methyl-CpG binding protein 2 (MeCP2), which is related with neurodevelopmental disorders such as Rett syndrome (155). This interaction between YBX1 and $\mathrm{MeCP} 2$ is dependent on RNA, and influences RNA splicing. Furthermore, after maternal immune activation, the expression of YBX1 is rapidly increased in the fetal brain, however, the possible role in adverse neurological outcomes has not been studied in this context (156).

\section{Cytosolic PSD-95 Interactor (Cypin)}

Mothers of autistic children showed antibody reactivity against Cypin, in $25 \%$ of cases, compared to $19 \%$ in mothers of typically developing children (Table 2) (127). Cypin is a guanine deaminase, which is required for the enzymatic degradation of the purine guanine to xanthine (157). Cypin is expressed in various organs in the body, but its highest expression is seen in epithelial cells of the intestine and in discrete neurons in the cortex, hippocampus and the superior colliculus (158). Importantly, Cypin has been found to be a major interaction protein for postsynaptic density protein 95 (PSD-95), and has both a structural and a regulatory role, decreasing localization of PSD-95 at post-synaptic sites (158). Cypin also promotes microtubule polymerization by directly binding to tubulin using a domain with high homology to collapsin response mediator protein (CRMP), another maternal autoantibody target described in autism $(127,159)$. This CRMPhomology domain and a 9 amino acid zinc-binding domain are required for guanine deaminase activity and for the regulation of dendrite branching and neuronal morphology in cultured hippocampal neurons $(159,160)$. Dendrite morphogenesis is essential for the communication between neurons and when the regulation of the dendritic arborization is altered, this can lead to abnormal spine density and morphology, synapse loss and aberrant synaptic signaling, resulting in modification of the neural circuitry which can lead to neuropsychiatric disorders $(14,161,162)$.

\section{Collapsin Response Mediator Proteins 1 and 2 (CRMP1/CRMP2)}

Antibodies to CRMP1 or CRMP2 have been found in 32 and $18 \%$ of mothers of ASD children, respectively, and in 18 and $7 \%$ of mothers of typically developing children (Table 2) (127). In addition, these autoantibodies are also found together with many of the other described autoantibodies in mothers of autistic children. The collapsin response mediator proteins are a family 
of five phosphoproteins (CRMP1-5) located in the cytosol of both neurons and glia (163). CRMP1 and CRMP2 are expressed both in the developing and the adult brain, but show peak expression in the last weeks of gestation and the first postnatal weeks (164). These proteins participate in the organization of the cytoskeleton and bind to microtubuli, actin filaments and intermediate filaments (165-168). During cell division, CRMP1 and 2 stabilize the mitotic apparatus, by binding to microtubuli (166). CRMP1 and CRMP2 are involved in radial migration and the subsequent differentiation of neurons during cortical development $(169,170)$. Furthermore, both proteins play a role in the regulation of signaling of class 3 semaphorins and neural growth cone collapse, remodeling of the cytoskeleton required for axonal growth and guidance, and dendritic arborization (171174). During neuronal polarization of cultured hippocampal neurons, CRMP2 becomes highly enriched in the distal part of the growing axon (172). On the other hand, when CRMP2 is overexpressed, these neurons develop multiple axons, while the expression of a truncated dominant negative mutant resulted in neurons with short or no axons. In addition, CRMP1 and CRMP2 are also required for proper dendritic patterning of cortical neurons. CRMP1 ${ }^{-/-}$mice show reduced dendrite length and reduced dendritic spine density, while $\mathrm{CRMP}^{-/-}$mice only have a reduced spine density (174). Both proteins seem to have some functional redundancy as inhibition of CRMP2 phosphorylation in a CRMP1 ${ }^{-/-}$background induces a strong disruption of the morphology, orientation and guidance of the dendrites of layer $\mathrm{V}$ cortical pyramidal neurons (175).

CRMP1 ${ }^{-/}$mice showed impaired memory and behavioral abnormalities related to schizophrenia such as hyperactivity, altered emotional behavior and decreased prepulse inhibition (176). On the other hand, brain-specific knockout of CRMP2 induced impairment of learning, memory and social behavior (177), while knock-in of a CRMP2 mutant with impaired phosphorylation reduced emotional behavior, sociality and pain sensitivity (178). Multiple genome-wide and proteomewide analyses have described gene variants or altered levels of CRMP1 and 2, but also other CRMP family members, in patients with neurodegenerative and neuropsychiatric disorders, such as Alzheimer disease, schizophrenia, mood disorders, epilepsy and neuropathic pain [reviewed in Quach et al. (179)].

\section{Stress-Induced Phosphoprotein 1 (STIP1)}

Mothers of ASD children showed antibody reactivity against STIP1, in $59 \%$ of cases, compared to $36 \%$ in mothers of typically developing children (Table 2) (127). In addition, anti-STIP1 antibodies were also found in many combinations with the other described maternal autoantibodies, resulting in strongly increased specificity. The Stress-induced phosphoprotein 1 (STIP1) is a co-chaperone of the heat shock proteins (Hsp)70 and Hsp90, and modulates their folding activity (180). STIP1 is mostly expressed in the cytosol, but it can also translocate to the nucleus (181), and even be secreted in exosomes, where it is found on the surface (182). Extracellular STIP1 was found to interact with the glycosylphosphatidylinositol (GPI)-anchored cellular prion protein $\mathrm{PrP}^{\mathrm{C}}$, leading to an increased number of neurons with neurites in vitro, without affecting the number or length of neurites per cell $(183,184)$. Moreover, this STIP1-PrPC interaction also protected cultured neurons from staurosporineinduced cell death. This STIP1-PrPC $\mathrm{C}_{\text {-induced neuritogenesis }}$ and neuroprotection was found to be mediated by $\mathrm{Ca}^{2+}$ signaling through the alpha7 nicotinic acetylcholine receptor (185). Interestingly, during glutamate-induced neurogenesis ex vivo, STIP1 and CRMP2 were among the most upregulated proteins (186). Moreover, STIP1 ${ }^{-/+}$heterozygous mice, which have a 50\% reduction of STIP expression without affecting Hsp70, Hsp90 or the $\mathrm{PrP}^{\mathrm{C}}$ levels, showed hyperactivity and attention deficits (187).

\section{Contactin-Associated Protein-Like 2 (CASPR2)}

Contactin-associated protein-like 2 (CASPR2) is a transmembrane cell adhesion protein of a subgroup of the neurexin family related to the establishment of the neural network and higher cognitive functions in the brain (188). The protein is encoded by the CNTNAP2 gene and is expressed both in the developing and adult nervous system $(189,190)$. In the developing human cortex, the anterior temporal and prefrontal regions have shown specific enrichment of CASPR2 (190). In adults, it is expressed in areas of the limbic circuit and in brain areas involved in motor activities and sensory pathways (191). At the subcellular level CASPR2 is located at the axon initial segment and in the nodes of Ranvier of myelinated axons, in presynaptic terminals of inhibitory neurons and in the postsynaptic compartment of excitatory neurons $(189,192)$. It is implicated in processes as diverse as nerve excitation and conduction, neurotransmitter release, organization of the axonal domain, dendritic spine stabilization, and neuronal network formation $(193,194)$.

Copy number variations and single nucleotide polymorphisms in the CNTNAP2 gene have been related to several neurodevelopmental disorders, such as schizophrenia, intellectual disability, epilepsy and autism, often with combined clinical presentation [reviewed in Saint-Martin et al. (188); Poot (195)]. Interestingly, genetic knockout of this gene in a mouse model induces the development of many of the core ASD behavioral symptoms, as CNTNAP2 $2^{-/-}$mice show increased repetitive behavior, decreased vocalization and decreased social interactions (196). In addition, these mice also display hyperactivity, hyper-reactivity to thermal sensory stimuli and epileptic seizures and allowed to study some of the underlying biology, with observed abnormalities in neuronal migration, a reduction in GABAergic interneurons and abnormal neuronal network activity.

In addition to the genetic variants affecting CASPR2 function, acquired dysfunction of CASPR2 has also been proposed in patients that form autoantibodies against CASPR2. Such antibodies have been described in patients with limbic encephalitis, Morvan syndrome and neuromyotonia, three conditions that variously affect the central and peripheral nervous system, and are characterized by cognitive decline, epilepsy, peripheral nerve hyperexcitability and neuropathic pain 
(197-199). Patient CASPR2 autoantibodies decreased AMPAtype glutamate receptor trafficking in cultured neurons and perturbed cortical excitatory transmission after stereotactic injection in the mouse visual cortex (200). Systemically injected patient CASPR2 autoantibodies did not cross the BBB and caused peripheral hypersensitivity to mechanical stimuli (201).

In contrast, in utero exposure to CASPR2 autoantibodies during embryonic development has been linked to the development of autistic features in the offspring (202). A monoclonal antibody with reactivity to CASPR2 was cloned from the memory $B$ cells of a mother with brain-reactive serology and a child with autism, and used in a passive transfer experiment in pregnant mice (202). The male offspring showed abnormal cortical development, together with a reduction in the dendritic complexity in excitatory neurons and a reduced number of inhibitory neurons, and presented with repetitive behaviors and impairment in learning and social abilities. In addition, purified human IgG from patients with CASPR2 immunoreactivity, could be found in the fetal circulation and fetal brain parenchyma after injection into pregnant mice (203). These offspring also showed deficits in social interaction, together with abnormal neuronal distribution, decrease in excitatory synapses and an increase in microglial activation (203). Among mothers of an autistic child that show brain-reactive antibodies, $37 \%$ were found to have autoantibodies that bind to CASPR2, compared to $12 \%$ in mothers of an autistic child lacking brain reactive antibodies and $8 \%$ of women of a normally developing child (202).

\section{CONCLUSION}

In conclusion, an increasing number of ASD-related autoantibodies have been described, both in ASD patients themselves and in mothers with children that later develop ASD.

At the moment, most of the antibodies which have been described in ASD patients still lack validation between independent research groups, and require testing in higher numbers of ASD patient and relevant control samples using standardized assays for a more reliable determination of their possible value as disease biomarkers. These autoantibodies have mostly been tested using a candidate approach, using autoantibodies which have already been described in other autoimmune diseases. This field might benefit from an unbiased screening of immunoreactivity in ASD patients, to identify potential new autoantibodies with a higher specificity for ASD. Because of the lack of functional studies using passive transfer of ASD patient antibodies in animal models, it is not known whether autoantibodies in ASD patients have an active

\section{REFERENCES}

1. American Psychiatric Association. Diagnostic and Statistical Manual of Mental Disorders. 5th Edn. Washington, DC: American Psychiatric Association (2013).

2. Baio J, Wiggins L, Christensen DL, Maenner MJ, Daniels J, Warren $\mathrm{Z}$, et al. Prevalence of autism spectrum disorder among children aged 8 years - autism and developmental disabilities monitoring network, contribution to the initiation or worsening of the disease. It could be that the presence of these antibodies is not directly related with the disease, considering the high prevalence in other disorders. Still, they might have indirect roles in the pathology or be related with subpopulations of ASD patients.

Autoantibodies in mothers of children that later develop ASD, have been found using a screening of immunoreactivity against relevant brain tissue, or in the case of CASPR2, by studying a protein which has already shown high relevance for ASD, and for which autoantibodies were previously described in other disorders. Individual specificities of these maternal antibodies are low, which could only be significantly increased using certain combinations of maternal antibody reactivity. These candidate markers also require validation by independent research groups, especially considering the specific set of combinations that have been described. However, an active contribution of certain autoantibodies in mothers, to the development of ASD in their children, is gaining more evidence. Passive transfer of IgG from mothers of ASD children in pregnant mice, or LDH$\mathrm{A} / \mathrm{B}$, STIP1- and CRMP1-immunization of female mice leads to relevant ASD-related biological and behavioral changes in the offspring. Individual relations of these autoantibodies to specific biological processes have not been established, and quite possibly, a combination of autoantibodies is required for a clear behavioral effect. Still, these are compelling models to further study the details of autoantibody-mediated disruption of early processes of neurodevelopment during pregnancy, eventually leading to behavioral deficits linked to ASD later in life.

\section{AUTHOR CONTRIBUTIONS}

RM-C wrote the manuscript and designed the figure and tables. PV wrote the manuscript, reviewed the manuscript structure, ideas, and science. VS evaluated and reviewed manuscript structure, ideas, and science. All authors read and approved the final manuscript.

\section{FUNDING}

The authors received financial support from the Research Foundation-Flanders (SB-FWO, 1S54717N, RM-C, Maternal antibodies as early biomarkers for Autism Spectrum Disorder) and the Simons Foundation Autism Research Initiative-Explorer Award (SFARI, 534849, VS, Maternal antibodies as early biomarkers for Autism Spectrum Disorder). 
5. Ornoy A, Weinstein-Fudim L, Ergaz Z. Genetic syndromes, maternal diseases and antenatal factors associated with autism spectrum disorders (ASD). Front Neurosci. (2016) 10:316. doi: 10.3389/fnins.2016.00316

6. Tordjman S. Gene $\mathrm{x}$ environment interactions in autism spectrum disorders: role of epigenetic mechanisms. Front Psychiat. (2014) 5:53. doi: 10.3389/fpsyt.2014.00053

7. Idring S, Magnusson C, Lundberg M, Ek M, Rai D, Svensson AC, et al. Parental age and the risk of autism spectrum disorders: findings from a Swedish population-based cohort. Int J Epidemiol. (2014) 43:107-15. doi: $10.1093 /$ ije/dyt262

8. Pagalan L, Bickford C, Weikum W, Lanphear B, Brauer M, Lanphear N, et al. Association of prenatal exposure to air pollution with autism spectrum disorder. JAMA Pediatr. (2018) 173:86-92. doi: 10.1001/jamapediatrics.2018.3101

9. Fitzgerald E, Boardman JP, Drake AJ. Preterm birth and the risk of neurodevelopmental disorders - is there a role for epigenetic dysregulation? Curr Genomics. (2018) 19:507-21. doi: 10.2174/1389202919666171229144807

10. Wolff JJ, Gu H, Gerig G, Elison JT, Styner M, Gouttard S, et al. Differences in white matter fiber tract development present from 6 to 24 months in infants with autism. Am J Psychiatry. (2012) 169:589-600. doi: 10.1176/appi.ajp.2011.11091447

11. Anderson JS, Lange N, Froehlich A, DuBray MB, Druzgal TJ, Froimowitz $\mathrm{MP}$, et al. Decreased left posterior insular activity during auditory language in autism. AJNR Am J Neuroradiol. (2010) 31:131-9. doi: 10.3174/ajnr.A1789

12. Park HR, Lee JM, Moon HE, Lee DS, Kim BN, Kim J, et al. A short review on the current understanding of autism spectrum disorders. Exp Neurobiol. (2016) 25:1-13. doi: 10.5607/en.2016.25.1.1

13. Tang G, Gudsnuk K, Kuo SH, Cotrina ML, Rosoklija G, Sosunov A, et al. Loss of mTOR-dependent macroautophagy causes autistic-like synaptic pruning deficits. Neuron. (2014) 83:1131-43. doi: 10.1016/j.neuron.2014.07.040

14. Kulkarni VA, Firestein BL. The dendritic tree and brain disorders. Mol Cell Neurosci. (2012) 50:10-20. doi: 10.1016/j.mcn.2012.03.005

15. Voineagu I, Eapen V. Converging pathways in autism spectrum disorders: interplay between synaptic dysfunction and immune responses. Front Hum Neurosci. (2013) 7:738. doi: 10.3389/fnhum.2013.00738

16. Li X. Elevated Immune response in the brain of autistic patients. $J$ Neuroimmunol. (2009) 207:111-6. doi: 10.1016/j.jneuroim.2008.12.002

17. Suzuki K, Sugihara G, Ouchi Y, Nakamura K, Futatsubashi M, Takebayashi $\mathrm{K}$, et al. Microglial activation in young adults with autism spectrum disorder. JAMA Psychiatry. (2013) 70:49-58. doi: 10.1001/jamapsychiatry. 2013.272

18. Vargas DL, Nascimbene C, Krishnan C, Zimmerman AW, Pardo CA. Neuroglial activation and neuroinflammation in the brain of patients with autism. Ann Neurol. (2005) 57:67-81. doi: 10.1002/ana.20315

19. Zimmerman AW, Jyonouchi H, Comi AM, Connors SL, Milstien S, Varsou A, et al. Cerebrospinal fluid and serum markers of inflammation in autism. Pediatr Neurol. (2005) 33:195-201. doi: 10.1016/j.pediatrneurol.2005.03.014

20. Meltzer AVdW, J. The role of the immune system in autism spectrum disorder. Neuropsychopharmacology. (2016) 42:284-98. doi: $10.1038 /$ npp. 2016.158

21. Brown AS. Epidemiologic studies of exposure to prenatal infection and risk of schizophrenia and autism. Dev Neurobiol. (2012) 72:1272-6. doi: 10.1002/dneu.22024

22. Hoffmann CZS, Mané-Damas M, Molenaar P, Losen M, Martinez-Martinez P. Autoantibodies in neuropsychiatric disorders. Antibodies. (2016) 5:9. doi: 10.3390/antib5020009

23. Adriani W, Romano E, Pucci M, Pascale E, Cerniglia L, Cimino S, et al. Potential for diagnosis versus therapy monitoring of attention deficit hyperactivity disorder: a new epigenetic biomarker interacting with both genotype and auto-immunity. Eur Child Adolesc Psychiatry. (2018) 27:24152. doi: 10.1007/s00787-017-1040-9

24. Parshukova D, Smirnova LP, Ermakov EA, Bokhan NA, Semke AV, Ivanova SA, et al. Autoimmunity and immune system dysregulation in schizophrenia: IgGs from sera of patients hydrolyze myelin basic protein. J Mol Recognit. (2018) 2018:e2759. doi: 10.1002/jmr.2759

25. Ferensztajn-Rochowiak E, Kaczmarek M, Wojcicka M, Kaufman-Szukalska E, Dziuda S, Remlinger-Molenda A, et al. Glutamate-related antibodies and peripheral insulin-like growth factor in bipolar disorder and lithium prophylaxis. Neuropsychobiology. (2019) 77:49-56. doi: 10.1159/000493740

26. Blome R, Bach W, Guli X, Porath K, Sellmann T, Bien CG, et al. Differentially altered NMDAR dependent and independent long-term potentiation in the CA3 subfield in a model of anti-NMDAR encephalitis. Front Synaptic Neurosci. (2018) 10:26. doi: 10.3389/fnsyn.2018.00026

27. Moscato EH, Peng X, Jain A, Parsons TD, Dalmau J, Balice-Gordon RJ. Acute mechanisms underlying antibody effects in anti-N-methyl-D-aspartate receptor encephalitis. Ann Neurol. (2014) 76:108-19. doi: 10.1002/ana.24195

28. Planagumà J, Leypoldt F, Mannara F, Gutiérrez-Cuesta J, Martín-García E, Aguilar E, et al. Human N-methyl D-aspartate receptor antibodies alter memory and behaviour in mice. Brain. (2015) 138(Pt 1):94-109. doi: 10.1093/brain/awu310

29. Titulaer MJ, McCracken L, Gabilondo I, Armangué T, Glaser C, Iizuka T, et al. Treatment and prognostic factors for long-term outcome in patients with anti-NMDA receptor encephalitis: an observational cohort study. Lancet Neurol. (2013) 12:157-65. doi: 10.1016/S1474-4422(12)70310-1

30. Dalton P, Deacon R, Blamire A, Pike M, McKinlay I, Stein J, et al. Maternal neuronal antibodies associated with autism and a language disorder. Ann Neurol. (2003) 53:533-7. doi: 10.1002/ana.10557

31. Todd RD, Ciaranello RD. Demonstration of inter- and intraspecies differences in serotonin binding sites by antibodies from an autistic child. Proc Natl Acad Sci USA. (1985) 82:612-6. doi: 10.1073/pnas.82.2.612

32. Kim J, Mohanty S, Ganesan LP, Hua K, Jarjoura D, Hayton WL, et al. FcRn in the yolk sac endoderm of mouse is required for IgG transport to fetus. $J$ Immunol. (2009) 182:2583-9. doi: 10.4049/jimmunol.0803247

33. Kowal C, Athanassiou A, Chen H, Diamond B. Maternal antibodies and developing blood-brain barrier. Immunol Res. (2015) 63:18-25. doi: 10.1007/s12026-015-8714-5

34. Cook EH Jr, Arora RC, Anderson GM, Berry-Kravis EM, Yan SY, Yeoh HC, et al. Platelet serotonin studies in hyperserotonemic relatives of children with autistic disorder. Life Sci. (1993) 52:2005-15. doi: 10.1016/0024-3205(93)90685-V

35. Yuwiler A, Shih JC, Chen CH, Ritvo ER, Hanna G, Ellison GW, et al. Hyperserotoninemia and antiserotonin antibodies in autism and other disorders. J Autism Dev Disord. (1992) 22:33-45. doi: 10.1007/BF01046401

36. Singh VK, Warren RP, Odell JD, Warren WL, Cole P. Antibodies to myelin basic protein in children with autistic behavior. Brain Behav Immun. (1993) 7:97-103. doi: 10.1006/brbi.1993.1010

37. Libbey JE, Coon HH, Kirkman NJ, Sweeten TL, Miller JN, Stevenson EK, et al. Are there enhanced MBP autoantibodies in autism? J Autism Dev Disord. (2008) 38:324-32. doi: 10.1007/s10803-007-0400-6

38. Connolly AM, Chez M, Streif EM, Keeling RM, Golumbek PT, Kwon $\mathrm{JM}$, et al. Brain-derived neurotrophic factor and autoantibodies to neural antigens in sera of children with autistic spectrum disorders, LandauKleffner syndrome, and epilepsy. Biol Psychiatry. (2006) 59:354-63. doi: 10.1016/j.biopsych.2005.07.004

39. Mostafa GA, Al-Ayadhi LY. A lack of association between hyperserotonemia and the increased frequency of serum anti-myelin basic protein autoantibodies in autistic children. J Neuroinflammation. (2011) 8:71. doi: 10.1186/1742-2094-8-71

40. Vojdani A, Campbell AW, Anyanwu E, Kashanian A, Bock K, Vojdani E. Antibodies to neuron-specific antigens in children with autism: possible cross-reaction with encephalitogenic proteins from milk, Chlamydia pneumoniae and Streptococcus group A. J Neuroimmunol. (2002) 129:16877. doi: 10.1016/S0165-5728(02)00180-7

41. Singh VK, Warren R, Averett R, Ghaziuddin M. Circulating autoantibodies to neuronal and glial filament proteins in autism. Pediatr Neurol. (1997) 17:88-90. doi: 10.1016/S0887-8994(97)00045-3

42. Mostafa GA, Al-Ayadhi LY. The possible link between the elevated serum levels of neurokinin $\mathrm{A}$ and anti-ribosomal $\mathrm{P}$ protein antibodies in children with autism. J Neuroinflammation. (2011) 8:180. doi: 10.1186/1742-2094-8-180

43. Evers M, Cunningham-Rundles C, Hollander E. Heat shock protein 90 antibodies in autism. Mol Psychiatry. (2002) 7 (Suppl. 2):S26-8. doi: $10.1038 /$ sj.mp.4001171

44. Russo AF. Anti-metallothionein IgG and levels of metallothionein in autistic families. Swiss Med Wkly. (2008) 138:70-7. 
45. Rout UK, Mungan NK, Dhossche DM. Presence of GAD65 autoantibodies in the serum of children with autism or ADHD. Eur Child Adolesc Psychiatry. (2012) 21:141-7. doi: 10.1007/s00787-012-0245-1

46. Mostafa GA, Al-Ayadhi LY. Increased serum levels of anti-ganglioside M1 auto-antibodies in autistic children: relation to the disease severity. J Neuroinflammation. (2011) 8:39. doi: 10.1186/1742-20948-39

47. Yang X, Liang S, Wang L, Han P, Jiang X, Wang J, et al. Sialic acid and antiganglioside antibody levels in children with autism spectrum disorders. Brain Res. (2018) 1678:273-7. doi: 10.1016/j.brainres.2017.10.027

48. Mostafa GA, El-Sherif DF, Al-Ayadhi LY. Systemic auto-antibodies in children with autism. J Neuroimmunol. (2014) 272:94-8. doi: 10.1016/j.jneuroim.2014.04.011

49. LY AL-A, Mostafa GA. Serum antinucleosome-specific antibody as a marker of autoimmunity in children with autism. J Neuroinflammation. (2014) 11:69. doi: 10.1186/1742-2094-11-69

50. Connolly AM, Chez MG, Pestronk A, Arnold ST, Mehta S, Deuel RK. Serum autoantibodies to brain in Landau-Kleffner variant, autism, and other neurologic disorders. J Pediatr. (1999) 134:607-13. doi: 10.1016/S0022-3476(99)70248-9

51. Mostafa GA, Kitchener N. Serum anti-nuclear antibodies as a marker of autoimmunity in Egyptian autistic children. Pediatr Neurol. (2009) 40:10712. doi: $10.1016 /$ j.pediatrneurol.2008.10.017

52. Kealy J, Greene C, Campbell M. Blood-brain barrier regulation in psychiatric disorders. Neurosci Lett. (2018). doi: 10.1016/j.neulet.2018.06.033. [Epub ahead of print].

53. Noble PW, Bernatsky S, Clarke AE, Isenberg DA, Ramsey-Goldman R, Hansen JE. DNA-damaging autoantibodies and cancer: the lupus butterfly theory. Nat Rev Rheumatol. (2016) 12:429-34. doi: 10.1038/nrrheum.2016.23

54. Boggs JM. Myelin basic protein: a multifunctional protein. Cell Mol Life Sci. (2006) 63:1945-61. doi: 10.1007/s00018-006-6094-7

55. Barbarese E, Barry C, Chou CH, Goldstein DJ, Nakos GA, HydeDeRuyscher R, et al. Expression and localization of myelin basic protein in oligodendrocytes and transfected fibroblasts. J Neurochem. (1988) 51:173745. doi: 10.1111/j.1471-4159.1988.tb01153.x

56. Ozgen H, Baron W, Hoekstra D, Kahya N. Oligodendroglial membrane dynamics in relation to myelin biogenesis. Cell Mol Life Sci. (2016) 73:3291310. doi: 10.1007/s00018-016-2228-8

57. Kinney HC, Volpe JJ. Chapter 8: Myelination events. In: Volpe JJ, Inder TE, Darras BT, de Vries LS, du Plessis AJ, Neil JJ, Perlman JM. editors. Volpe's Neurology of the Newborn. Elsevier (2018). p. 176-88. doi: 10.1016/B978-0-323-42876-7.00008-9

58. Baptista TSA, Petersen LE, Molina JK, de Nardi T, Wieck A, do Prado A, et al. Autoantibodies against myelin sheath and S100beta are associated with cognitive dysfunction in patients with rheumatoid arthritis. Clin Rheumatol. (2017) 36:1959-68. doi: 10.1007/s10067-017-3724-4

59. Catani M, Dell'Acqua F, Budisavljevic S, Howells H, Thiebaut de Schotten $\mathrm{M}$, Froudist-Walsh S, et al. Frontal networks in adults with autism spectrum disorder. Brain. (2016) 139(Pt 2):616-30. doi: 10.1093/brain/awv351

60. D’Aversa TG, Eugenin EA, Lopez L, Berman JW. Myelin basic protein induces inflammatory mediators from primary human endothelial cells and blood-brain barrier disruption: implications for the pathogenesis of multiple sclerosis. Neuropathol Appl Neurobiol. (2013) 39:270-83. doi: 10.1111/j.1365-2990.2012.01279.x

61. Weizman A, Weizman R, Szekely GA, Wijsenbeek H, Livni E. Abnormal immune response to brain tissue antigen in the syndrome of autism. Am J Psychiatry. (1982) 139:1462-5. doi: 10.1176/ajp.139. 11.1462

62. Warren RP, Margaretten NC, Pace NC, Foster A. Immune abnormalities in patients with autism. J Autism Dev Disord. (1986) 16:189-97. doi: 10.1007/BF01531729

63. Link H, Baig S, Jiang YP, Olsson O, Hojeberg B, Kostulas V, et al. B cells and antibodies in MS. Res Immunol. (1989) 140:219-26; discussion 45-8. doi: 10.1016/0923-2494(89)90091-6

64. Fraussen J. Targets of the humoral autoimmune response in multiple sclerosis. Autoimmun Rev. (2014) 13:1126-37. doi: 10.1016/j.autrev.2014.07.002
65. Papuc E, Kurzepa J, Kurys-Denis E, Grabarska A, Krupski W, Rejdak K. Humoral response against glial derived antigens in Parkinson's disease. Neurosci Lett. (2014) 566:77-81. doi: 10.1016/j.neulet.2014.02.043

66. Mostafa GA, Al-Ayadhi LY. The possible relationship between allergic manifestations and elevated serum levels of brain specific autoantibodies in autistic children. J Neuroimmunol. (2013) 261:77-81. doi: 10.1016/j.jneuroim.2013.04.003

67. Yuan A, Rao MV, Veeranna, Nixon RA. Neurofilaments and neurofilament proteins in health and disease. Cold Spring Harb Perspect Biol. (2017) 9:a018309. doi: 10.1101/cshperspect.a018309

68. Collard JF, Cote F, Julien JP. Defective axonal transport in a transgenic mouse model of amyotrophic lateral sclerosis. Nature. (1995) 375:61-4. doi: $10.1038 / 375061 \mathrm{a} 0$

69. Camacho J, Jones K, Miller E, Ariza J, Noctor S, Van de Water J, et al. Embryonic intraventricular exposure to autism-specific maternal autoantibodies produces alterations in autistic-like stereotypical behaviors in offspring mice. Behav Brain Res. (2014) 266:46-51. doi: 10.1016/j.bbr.2014.02.045

70. Sihag RK, Inagaki $M$, Yamaguchi $T$, Shea TB, Pant HC. Role of phosphorylation on the structural dynamics and function of types III and IV intermediate filaments. Exp Cell Res. (2007) 313:2098-109. doi: 10.1016/j.yexcr.2007.04.010

71. Kaczmarski W, Barua M, Mazur-Kolecka B, Frackowiak J, Dowjat W, Mehta P, et al. Intracellular distribution of differentially phosphorylated dual-specificity tyrosine phosphorylation-regulated kinase 1A (DYRK1A). J Neurosci Res. (2014) 92:162-73. doi: 10.1002/jnr.23279

72. Figlewicz DA, Krizus A, Martinoli MG, Meininger V, Dib M, Rouleau GA, et al. Variants of the heavy neurofilament subunit are associated with the development of amyotrophic lateral sclerosis. Hum Mol Genet. (1994) 3:1757-61. doi: 10.1093/hmg/3.10.1757

73. Rebelo AP, Abrams AJ, Cottenie E, Horga A, Gonzalez M, Bis DM, et al. Cryptic amyloidogenic elements in the 3' UTRs of neurofilament genes trigger axonal neuropathy. Am J Hum Genet. (2016) 98:597-614. doi: 10.1016/j.ajhg.2016.02.022

74. Bartos A, Fialova L, Svarcova J, Ripova D. Patients with Alzheimer disease have elevated intrathecal synthesis of antibodies against tau protein and heavy neurofilament. J Neuroimmunol. (2012) 252:100-5. doi: 10.1016/j.jneuroim.2012.08.001

75. Soussan L, Tchernakov K, Bachar-Lavi O, Yuvan T, Wertman E, Michaelson DM. Antibodies to different isoforms of the heavy neurofilament protein (NF-H) in normal aging and Alzheimer's disease. Mol Neurobiol. (1994) 9:83-91. doi: 10.1007/BF02816107

76. Fialova L, Bartos A, Svarcova J, Zimova D, Kotoucova J. Serum and cerebrospinal fluid heavy neurofilaments and antibodies against them in early multiple sclerosis. J Neuroimmunol. (2013) 259:81-7. doi: 10.1016/j.jneuroim.2013.03.009

77. Toh BH, Gibbs CJ Jr, Gajdusek DC, Tuthill DD, Dahl D. The 200- and 150$\mathrm{kDa}$ neurofilament proteins react with IgG autoantibodies from chimpanzees with kuru or Creutzfeldt-Jakob disease; a 62-kDa neurofilament-associated protein reacts with sera from sheep with natural scrapie. Proc Natl Acad Sci USA. (1985) 82:3894-6. doi: 10.1073/pnas.82.11.3894

78. Yang Z, Wang KK. Glial fibrillary acidic protein: from intermediate filament assembly and gliosis to neurobiomarker. Trends Neurosci. (2015) 38:364-74. doi: 10.1016/j.tins.2015.04.003

79. Eng LF, Ghirnikar RS. GFAP and astrogliosis. Brain Pathol. (1994) 4:229-37. doi: 10.1111/j.1750-3639.1994.tb00838.x

80. Plog BA, Dashnaw ML, Hitomi E, Peng W, Liao Y, Lou N, et al. Biomarkers of traumatic injury are transported from brain to blood via the glymphatic system. J Neurosci. (2015) 35:518-26. doi: 10.1523/JNEUROSCI.3742-14.2015

81. Hergenroeder GW, Redell JB, Choi HA, Schmitt L, Donovan W, Francisco GE, et al. Increased levels of circulating glial fibrillary acidic protein and collapsin response mediator protein-2 autoantibodies in the acute stage of spinal cord injury predict the subsequent development of neuropathic pain. J Neurotrauma. (2018) 35:2530-9. doi: 10.1089/neu.2018.5675

82. Zhang Z, Zoltewicz JS, Mondello S, Newsom KJ, Yang Z, Yang B, et al. Human traumatic brain injury induces autoantibody response against glial fibrillary 
acidic protein and its breakdown products. PLoS ONE. (2014) 9:e92698. doi: 10.1371/journal.pone.0092698

83. Rosengren LE, Ahlsen G, Belfrage M, Gillberg C, Haglid KG, Hamberger A. A sensitive ELISA for glial fibrillary acidic protein: application in CSF of children. J Neurosci Methods. (1992) 44:113-9. doi: 10.1016/0165-0270(92)90004-W

84. Laurence JA, Fatemi SH. Glial fibrillary acidic protein is elevated in superior frontal, parietal and cerebellar cortices of autistic subjects. Cerebellum. (2005) 4:206-10. doi: 10.1080/14734220500208846

85. Esnafoglu E, Ayyildiz SN, Cirrik S, Erturk EY, Erdil A, Dagli A, et al. Evaluation of serum Neuron-specific enolase, S100B, myelin basic protein and glial fibrilliary acidic protein as brain specific proteins in children with autism spectrum disorder. Int J Dev Neurosci. (2017) 61:86-91. doi: 10.1016/j.ijdevneu.2017.06.011

86. Wang P, Qin D, Wang YF. Oxytocin rapidly changes astrocytic GFAP plasticity by differentially modulating the expressions of pERK 1/2 and protein kinase A. Front Mol Neurosci. (2017) 10:262. doi: $10.3389 /$ fnmol.2017.00262

87. Kirkman NJ, Libbey JE, Sweeten TL, Coon HH, Miller JN, Stevenson EK, et al. How relevant are GFAP autoantibodies in autism and Tourette Syndrome? J Autism Dev Disord. (2008) 38:333-41. doi: 10.1007/s10803-007-0398-9

88. Castello A, Fischer B, Eichelbaum K, Horos R, Beckmann BM, Strein C, et al. Insights into RNA biology from an atlas of mammalian mRNA-binding proteins. Cell. (2012) 149:1393-406. doi: 10.1016/j.cell.2012.04.031

89. Odintsova TI, Muller EC, Ivanov AV, Egorov TA, Bienert R, Vladimirov $\mathrm{SN}$, et al. Characterization and analysis of posttranslational modifications of the human large cytoplasmic ribosomal subunit proteins by mass spectrometry and Edman sequencing. J Protein Chem. (2003) 22:249-58. doi: 10.1023/A:1025068419698

90. Rich BE, Steitz JA. Human acidic ribosomal phosphoproteins P0, P1, and P2: analysis of cDNA clones, in vitro synthesis, and assembly. Mol Cell Biol. (1987) 7:4065-74. doi: 10.1128/MCB.7.11.4065

91. Valoes CC, Molinari BC, Pitta AC, Gormezano NW, Farhat SC, Kozu $\mathrm{K}$, et al. Anti-ribosomal P antibody: a multicenter study in childhoodonset systemic lupus erythematosus patients. Lupus. (2017) 26:484-9. doi: $10.1177 / 0961203316676386$

92. Gerli R, Caponi L. Anti-ribosomal P protein antibodies. Autoimmunity. (2005) 38:85-92. doi: 10.1080/08916930400022699

93. Calich AL, Viana VS, Cancado E, Tustumi F, Terrabuio DR, Leon EP, et al. Anti-ribosomal P protein: a novel antibody in autoimmune hepatitis. Liver Int. (2013) 33:909-13. doi: 10.1111/liv.12155

94. Sciascia S, Bertolaccini ML, Roccatello D, Khamashta MA, Sanna G. Autoantibodies involved in neuropsychiatric manifestations associated with systemic lupus erythematosus: a systematic review. J Neurol. (2014) 261:1706-14. doi: 10.1007/s00415-014-7406-8

95. Matus S, Burgos PV, Bravo-Zehnder M, Kraft R, Porras OH, Farias P, et al. Antiribosomal-P autoantibodies from psychiatric lupus target a novel neuronal surface protein causing calcium influx and apoptosis. J Exp Med. (2007) 204:3221-34. doi: 10.1084/jem.20071285

96. Bravo-Zehnder M, Toledo EM, Segovia-Miranda F, Serrano FG, Benito MJ, Metz C, et al. Anti-ribosomal P protein autoantibodies from patients with neuropsychiatric lupus impair memory in mice. Arthritis Rheumatol. (2015) 67:204-14. doi: 10.1002/art.38900

97. Gaburo N Jr, de Carvalho JF, Timo-Iaria CIM, Bueno C, Reichlin M, Viana VS, et al. Electrophysiological dysfunction induced by anti-ribosomal $\mathrm{P}$ protein antibodies injection into the lateral ventricle of the rat brain. Lupus. (2017) 26:463-9. doi: 10.1177/0961203316666185

98. Mostafa GA, Bjorklund G, Urbina MA, Al-Ayadhi LY. The positive association between elevated blood lead levels and brain-specific autoantibodies in autistic children from low lead-polluted areas. Metab Brain Dis. (2016) 31:1047-54. doi: 10.1007/s11011-016-9836-8

99. Hoter A, El-Sabban ME, Naim HY. The HSP90 Family: structure, regulation, function, and implications in health and disease. Int J Mol Sci. (2018) 19:2560. doi: 10.3390/ijms19092560

100. Juarez-Rebollar D, Rios C, Nava-Ruiz C, Mendez-Armenta M. Metallothionein in brain disorders. Oxid Med Cell Longev. (2017) 2017:5828056. doi: 10.1155/2017/5828056
101. Campisi L, Imran N, Nazeer A, Skokauskas N, Azeem MW. Autism spectrum disorder. Br Med Bull. (2018) 127:91-100. doi: 10.1093/bmb/ ldy026

102. Li H, Li H, Li Y, Liu Y, Zhao Z. Blood mercury, arsenic, cadmium, and lead in children with autism spectrum disorder. Biol Trace Elem Res. (2018) 181:31-7. doi: 10.1007/s12011-017-1002-6

103. Chen L, Jin T, Huang B, Chang X, Lei L, Nordberg GF, et al. Plasma Metallothionein antibody and cadmium-induced renal dysfunction in an occupational population in China. Toxicol Sci. (2006) 91:104-12. doi: $10.1093 /$ toxsci/kfj053

104. Jin GB, Nakayama H, Shmyhlo M, Inoue S, Kondo M, Ikezawa Z, et al. High positive frequency of antibodies to metallothionein and heat shock protein 70 in sera of patients with metal allergy. Clin Exp Immunol. (2003) 131:275-9. doi: 10.1046/j.1365-2249.2003.02074.x

105. Russo AJ. Anti-metallothionein IgG and levels of metallothionein in autistic children with GI disease. Drug Healthc Patient Saf. (2009) 1:1-8. doi: 10.2147/DHPS.S4342

106. Asada H, Kawamura Y, Maruyama K, Kume H, Ding R, Ji FY, et al. Mice lacking the $65 \mathrm{kDa}$ isoform of glutamic acid decarboxylase (GAD65) maintain normal levels of GAD67 and GABA in their brains but are susceptible to seizures. Biochem Biophys Res Commun. (1996) 229:891-5. doi: 10.1006/bbrc.1996.1898

107. Mitoma H, Manto M, Hampe CS. Pathogenic roles of glutamic acid decarboxylase 65 autoantibodies in cerebellar ataxias. J Immunol Res. (2017) 2017:2913297. doi: 10.1155/2017/2913297

108. London F, Hadhoum N, Zephir H, Outteryck O, Vermersch P. Autoimmune cerebellar ataxia with glutamic acid decarboxylase 65 antibodies associated with central vestibular symptoms. Acta Neurol Belg. (2017) 117:775-6. doi: 10.1007/s13760-016-0733-z

109. McKeon A, Tracy JA. GAD65 neurological autoimmunity. Muscle Nerve. (2017) 56:15-27. doi: 10.1002/mus.25565

110. Daif A, Lukas RV, Issa NP, Javed A, VanHaerents S, Reder AT, et al. Antiglutamic acid decarboxylase 65 (GAD65) antibody-associated epilepsy. Epilepsy Behav. (2018) 80:331-6. doi: 10.1016/j.yebeh.2018.01.021

111. Aureli M, Mauri L, Ciampa MG, Prinetti A, Toffano G, Secchieri C, et al. GM1 ganglioside: past studies and future potential. Mol Neurobiol. (2016) 53:1824-42. doi: 10.1007/s12035-015-9136-z

112. Mocchetti I. Exogenous gangliosides, neuronal plasticity and repair, and the neurotrophins. Cell Mol Life Sci. (2005) 62:2283-94. doi: 10.1007/s00018-005-5188-y

113. Bansal AS, Abdul-Karim B, Malik RA, Goulding P, Pumphrey RS, Boulton $\mathrm{AJ}$, et al. IgM ganglioside GM1 antibodies in patients with autoimmune disease or neuropathy, and controls. J Clin Pathol. (1994) 47:300-2. doi: $10.1136 /$ jcp.47.4.300

114. Hatzifilippou E, Koutsouraki E, Costa VG, Baloyannis SJ. Antibodies against gangliosides in patients with dementia. Am J Alzheimers Dis Other Demen. (2014) 29:660-6. doi: 10.1177/1533317514534953

115. Nobile-Orazio E, Giannotta C, Musset L, Messina P, Leger JM. Sensitivity and predictive value of anti-GM1/galactocerebroside IgM antibodies in multifocal motor neuropathy. J Neurol Neurosurg Psychiatry. (2014) 85:7548. doi: 10.1136/jnnp-2013-305755

116. Lardone RD, Yuki N, Irazoqui FJ, Nores GA. Individual restriction of fine specificity variability in anti-gm1 igg antibodies associated with guillainbarre syndrome. Sci Rep. (2016) 6:19901. doi: 10.1038/srep19901

117. Vlagea A, Falagan S, Gutierrez-Gutierrez G, Moreno-Rubio J, Merino M, Zambrana F, et al. Antinuclear antibodies and cancer: a literature review. Crit Rev Oncol Hematol. (2018) 127:42-9. doi: 10.1016/j.critrevonc.2018.05.002

118. Tan EM, Schur PH, Carr RI, Kunkel HG. Deoxybonucleic acid (DNA) and antibodies to DNA in the serum of patients with systemic lupus erythematosus. J Clin Invest. (1966) 45:1732-40. doi: 10.1172/JCI105479

119. Chabre H, Amoura Z, Piette JC, Godeau P, Bach JF, Koutouzov S. Presence of nucleosome-restricted antibodies in patients with systemic lupus erythematosus. Arthritis Rheum. (1995) 38:1485-91. doi: 10.1002/art.1780381015

120. Chhabra S, Bharti S, Minz RW, Bhardwaj R, Pasricha N. Tissue antinuclear antibodies in renal biopsies of patients with systemic connective tissue disorders. J Nat Sci Biol Med. (2015) 6:279-80. doi: $10.4103 / 0976-9668.149250$ 
121. Nolph KD, Ghods AJ, Sharp GC, Siemsen AW. Antibodies to nuclear antigens in patients with renal failure. J Lab Clin Med. (1978) 91:559-67.

122. Kalaaji M, Fenton KA, Mortensen ES, Olsen R, Sturfelt G, Alm P, et al. Glomerular apoptotic nucleosomes are central target structures for nephritogenic antibodies in human SLE nephritis. Kidney Int. (2007) 71:66472. doi: 10.1038/sj.ki.5002133

123. Yung S, Chan TM. Autoantibodies and resident renal cells in the pathogenesis of lupus nephritis: getting to know the unknown. Clin Dev Immunol. (2012) 2012:139365. doi: 10.1155/2012/139365

124. Sur LM, Floca E, Sur DG, Colceriu MC, Samasca G, Sur G. Antinuclear antibodies: marker of diagnosis and evolution in autoimmune diseases. Lab Med. (2018) 49:e62-e73. doi: 10.1093/labmed/lmy024

125. Palmeira P, Quinello C, Silveira-Lessa AL, Zago CA, Carneiro-Sampaio M. IgG placental transfer in healthy and pathological pregnancies. Clin Dev Immunol. (2012) 2012:985646. doi: 10.1155/2012/985646

126. Warren RP, Cole P, Odell JD, Pingree CB, Warren WL, White E, et al. Detection of maternal antibodies in infantile autism. J Am Acad Child Adolesc Psychiatry. (1990) 29:873-7. doi: 10.1097/00004583-199011000-00005

127. Braunschweig D, Krakowiak P, Duncanson P, Boyce R, Hansen RL, Ashwood $\mathrm{P}$, et al. Autism-specific maternal autoantibodies recognize critical proteins in developing brain. Transl Psychiatry. (2013) 3:e277. doi: 10.1038/tp.2013.50

128. Singer HS, Morris CM, Gause CD, Gillin PK, Crawford S, Zimmerman AW. Antibodies against fetal brain in sera of mothers with autistic children. $J$ Neuroimmunol. (2008) 194:165-72. doi: 10.1016/j.jneuroim.2007.11.004

129. Brimberg L, Sadiq A, Gregersen PK, Diamond B. Brain-reactive IgG correlates with autoimmunity in mothers of a child with an autism spectrum disorder. Mol Psychiatry. (2013) 18:1171-7. doi: 10.1038/mp. 2013.101

130. Zimmerman AW, Connors SL, Matteson KJ, Lee LC, Singer HS, Castaneda JA, et al. Maternal antibrain antibodies in autism. Brain Behav Immun. (2007) 21:351-7. doi: 10.1016/j.bbi.2006.08.005

131. Croen LA, Braunschweig D, Haapanen L, Yoshida CK, Fireman B, Grether $\mathrm{JK}$, et al. Maternal mid-pregnancy autoantibodies to fetal brain protein: the early markers for autism study. Biol Psychiatry. (2008) 64:583-8. doi: 10.1016/j.biopsych.2008.05.006

132. Goines P, Haapanen L, Boyce R, Duncanson P, Braunschweig D, Delwiche L, et al. Autoantibodies to cerebellum in children with autism associate with behavior. Brain Behav Immun. (2011) 25:514-23. doi: 10.1016/j.bbi.2010.11.017

133. Braunschweig D, Ashwood P, Krakowiak P, Hertz-Picciotto I, Hansen R, Croen LA, et al. Autism: maternally derived antibodies specific for fetal brain proteins. Neurotoxicology. (2008) 29:226-31. doi: 10.1016/j.neuro.2007.10.010

134. Heuer L, Braunschweig D, Ashwood P, Van de Water J, Campbell DB. Association of a MET genetic variant with autism-associated maternal autoantibodies to fetal brain proteins and cytokine expression. Transl Psychiatry. (2011) 1:e48. doi: 10.1038/tp.2011.48

135. Braunschweig D, Duncanson P, Boyce R, Hansen R, Ashwood P, Pessah IN, et al. Behavioral correlates of maternal antibody status among children with autism. J Autism Dev Disord. (2012) 42:1435-45. doi: 10.1007/s10803-011-1378-7

136. Nordahl CW, Braunschweig D, Iosif AM, Lee A, Rogers S, Ashwood P, et al. Maternal autoantibodies are associated with abnormal brain enlargement in a subgroup of children with autism spectrum disorder. Brain Behav Immun. (2013) 30:61-5. doi: 10.1016/j.bbi.2013.01.084

137. Braunschweig D, Golub MS, Koenig CM, Qi L, Pessah IN, Van de Water J, et al. Maternal autism-associated IgG antibodies delay development and produce anxiety in a mouse gestational transfer model. J Neuroimmunol. (2012) 252:56-65. doi: 10.1016/j.jneuroim.2012.08.002

138. Ariza J, Hurtado J, Rogers H, Ikeda R, Dill M, Steward C, et al. Maternal autoimmune antibodies alter the dendritic arbor and spine numbers in the infragranular layers of the cortex. PLoS ONE. (2017) 12:e0183443. doi: 10.1371 /journal.pone. 0183443

139. Singer HS, Morris C, Gause C, Pollard M, Zimmerman AW, Pletnikov M. Prenatal exposure to antibodies from mothers of children with autism produces neurobehavioral alterations: a pregnant dam mouse model. $J$ Neuroimmunol. (2009) 211:39-48. doi: 10.1016/j.jneuroim.2009.03.011
140. Edmiston E, Jones KL, Vu T, Ashwood P, Van de Water J. Identification of the antigenic epitopes of maternal autoantibodies in autism spectrum disorders. Brain Behav Immun. (2018) 69:399-407. doi: 10.1016/j.bbi.2017.12.014

141. Jones KL, Pride MC, Edmiston E, Yang M, Silverman JL, Crawley JN, et al. Autism-specific maternal autoantibodies produce behavioral abnormalities in an endogenous antigen-driven mouse model of autism. Mol Psychiatry. (2018). doi: 10.1038/s41380-018-0126-1. [Epub ahead of print].

142. Martinez-Cerdeno V, Camacho J, Fox E, Miller E, Ariza J, Kienzle D, et al. Prenatal exposure to autism-specific maternal autoantibodies alters proliferation of cortical neural precursor cells, enlarges brain, and increases neuronal size in adult animals. Cereb Cortex. (2016) 26:374-83. doi: 10.1093/cercor/bhu291

143. Valvona CJ, Fillmore HL, Nunn PB, Pilkington GJ. The regulation and function of lactate dehydrogenase a: therapeutic potential in brain tumor. Brain Pathol. (2016) 26:3-17. doi: 10.1111/bpa.12299

144. Laughton JD, Charnay Y, Belloir B, Pellerin L, Magistretti PJ, Bouras C. Differential messenger RNA distribution of lactate dehydrogenase LDH1 and LDH-5 isoforms in the rat brain. Neuroscience. (2000) 96:619-25. doi: 10.1016/S0306-4522(99)00580-1

145. Khemakhem AM, Frye RE, El-Ansary A, Al-Ayadhi L, Bacha AB. Novel biomarkers of metabolic dysfunction is autism spectrum disorder: potential for biological diagnostic markers. Metab Brain Dis. (2017) 32:1983-97. doi: 10.1007/s11011-017-0085-2

146. Rossignol DA, Frye RE. Mitochondrial dysfunction in autism spectrum disorders: a systematic review and meta-analysis. Mol Psychiatry. (2012) 17:290-314. doi: 10.1038/mp.2010.136

147. Hollis F, Kanellopoulos AK, Bagni C. Mitochondrial dysfunction in Autism Spectrum Disorder: clinical features and perspectives. Curr Opin Neurobiol. (2017) 45:178-87. doi: 10.1016/j.conb.2017.05.018

148. Rose S, Niyazov DM, Rossignol DA, Goldenthal M, Kahler SG, Frye RE. Clinical and molecular characteristics of mitochondrial dysfunction in autism spectrum disorder. Mol Diagn Ther. (2018) 22:571-93. doi: 10.1007/s40291-018-0352-x

149. Didier DK, Schiffenbauer J, Woulfe SL, Zacheis M, Schwartz BD. Characterization of the CDNA encoding a protein binding to the major histocompatibility complex class II Y box. Proc Natl Acad Sci USA. (1988) 85:7322-6. doi: 10.1073/pnas.85.19.7322

150. Lyabin DN, Eliseeva IA, Ovchinnikov LP. YB-1 protein: functions and regulation. Wiley Interdiscip Rev RNA. (2014) 5:95-110. doi: $10.1002 /$ wrna. 1200

151. Fotovati A, Abu-Ali S, Wang PS, Deleyrolle LP, Lee C, Triscott J, et al. YB-1 bridges neural stem cells and brain tumor-initiating cells via its roles in differentiation and cell growth. Cancer Res. (2011) 71:5569-78. doi: 10.1158/0008-5472.CAN-10-2805

152. Lu ZH, Books JT, Ley TJ. Cold shock domain family members YB-1 and MSY4 share essential functions during murine embryogenesis. Mol Cell Biol. (2006) 26:8410-7. doi: 10.1128/MCB.01196-06

153. Bernstein HG, Lindquist JA, Keilhoff G, Dobrowolny H, Brandt S, Steiner J, et al. Differential distribution of Y-box-binding protein 1 and cold shock domain protein $\mathrm{A}$ in developing and adult human brain. Brain Struct Funct. (2015) 220:2235-45. doi: 10.1007/s00429-014-0 786-9

154. Uchiumi T, Fotovati A, Sasaguri T, Shibahara K, Shimada T, Fukuda T, et al. YB-1 is important for an early stage embryonic development: neural tube formation and cell proliferation. J Biol Chem. (2006) 281:40440-9. doi: 10.1074/jbc.M605948200

155. Young JI, Hong EP, Castle JC, Crespo-Barreto J, Bowman AB, Rose MF, et al. Regulation of RNA splicing by the methylation-dependent transcriptional repressor methyl-CpG binding protein 2. Proc Natl Acad Sci USA. (2005) 102:17551-8. doi: 10.1073/pnas.0507856102

156. Liverman CS, Kaftan HA, Cui L, Hersperger SG, Taboada E, Klein RM, et al. Altered expression of pro-inflammatory and developmental genes in the fetal brain in a mouse model of maternal infection. Neurosci Lett. (2006) 399:220-5. doi: 10.1016/j.neulet.2006.01.064

157. Yuan G, Bin JC, McKay DJ, Snyder FF. Cloning and characterization of human guanine deaminase. Purification and partial amino acid sequence of the mouse protein. I Biol Chem. (1999) 274:8175-80. doi: $10.1074 / j b c .274 .12 .8175$ 
158. Firestein BL, Firestein BL, Brenman JE, Aoki C, Sanchez-Perez AM, ElHusseini AE, et al. Cypin: a cytosolic regulator of PSD-95 postsynaptic targeting. Neuron. (1999) 24:659-72. doi: 10.1016/S0896-6273(00)81120-4

159. Akum BF, Chen M, Gunderson SI, Riefler GM, Scerri-Hansen MM, Firestein BL. Cypin regulates dendrite patterning in hippocampal neurons by promoting microtubule assembly. Nat Neurosci. (2004) 7:145-52. doi: $10.1038 / \mathrm{nn} 1179$

160. Patel MV, Swiatkowski P, Kwon M, Rodriguez AR, Campagno K, Firestein BL. A novel short isoform of cytosolic PSD-95 interactor (cypin) regulates neuronal development. Mol Neurobiol. (2018) 55:6269-81. doi: 10.1007/s12035-017-0849-z

161. Zoghbi HY. Postnatal neurodevelopmental disorders: meeting at the synapse? Science. (2003) 302:826-30. doi: 10.1126/science.1089071

162. Bourgeron T. From the genetic architecture to synaptic plasticity in autism spectrum disorder. Nat Rev Neurosci. (2015) 16:551-63. doi: $10.1038 / \mathrm{nrn} 3992$

163. Nagai J, Baba R, Ohshima T. CRMPs function in neurons and glial cells: potential therapeutic targets for neurodegenerative diseases and CNS injury. Mol Neurobiol. (2017) 54:4243-56. doi: 10.1007/s12035-0160005-1

164. Charrier E, Reibel S, Rogemond V, Aguera M, Thomasset N, Honnorat J. Collapsin response mediator proteins (CRMPs): involvement in nervous system development and adult neurodegenerative disorders. Mol Neurobiol. (2003) 28:51-64. doi: 10.1385/MN:28:1:51

165. Fukata Y, Itoh TJ, Kimura T, Menager C, Nishimura T, Shiromizu T, et al. CRMP-2 binds to tubulin heterodimers to promote microtubule assembly. Nat Cell Biol. (2002) 4:583-91. doi: 10.1038/ncb825

166. Lin PC, Chan PM, Hall C, Manser E. Collapsin response mediator proteins (CRMPs) are a new class of microtubule-associated protein (MAP) that selectively interacts with assembled microtubules via a taxol-sensitive binding interaction. J Biol Chem. (2011) 286:41466-78. doi: 10.1074/jbc.M111.283580

167. Rosslenbroich V, Dai L, Baader SL, Noegel AA, Gieselmann V, Kappler J. Collapsin response mediator protein 4 regulates F-actin bundling. Exp Cell Res. (2005) 310:434-44. doi: 10.1016/j.yexcr.2005.08.005

168. Varrin-Doyer M, Vincent P, Cavagna S, Auvergnon N, Noraz N, Rogemond $\mathrm{V}$, et al. Phosphorylation of collapsin response mediator protein 2 on Tyr479 regulates CXCL12-induced T lymphocyte migration. J Biol Chem. (2009) 284:13265-76. doi: 10.1074/jbc.M807664200

169. Yamashita N, Uchida Y, Ohshima T, Hirai S, Nakamura F, Taniguchi $\mathrm{M}$, et al. Collapsin response mediator protein 1 mediates reelin signaling in cortical neuronal migration. J Neurosci. (2006) 26:13357-62. doi: 10.1523/JNEUROSCI.4276-06.2006

170. Ip JP, Fu AK, Ip NY. CRMP2: functional roles in neural development and therapeutic potential in neurological diseases. Neuroscientist. (2014) 20:589-98. doi: 10.1177/1073858413514278

171. Goshima Y, Nakamura F, Strittmatter P, Strittmatter SM. Collapsin-induced growth cone collapse mediated by an intracellular protein related to UNC-33. Nature. (1995) 376:509-14. doi: 10.1038/376509a0

172. Inagaki N, Chihara K, Arimura N, Menager C, Kawano Y, Matsuo N, et al. CRMP-2 induces axons in cultured hippocampal neurons. Nat Neurosci. (2001) 4:781-2. doi: 10.1038/90476

173. Cole AR, Knebel A, Morrice NA, Robertson LA, Irving AJ, Connolly CN, et al. GSK-3 phosphorylation of the Alzheimer epitope within collapsin response mediator proteins regulates axon elongation in primary neurons. J Biol Chem. (2004) 279:50176-80. doi: 10.1074/jbc.C400412200

174. Makihara H, Nakai S, Ohkubo W, Yamashita N, Nakamura F, Kiyonari H, et al. CRMP1 and CRMP2 have synergistic but distinct roles in dendritic development. Genes Cells. (2016) 21:994-1005. doi: 10.1111/gtc.12399

175. Yamashita N, Ohshima T, Nakamura F, Kolattukudy P, Honnorat J, Mikoshiba K, et al. Phosphorylation of CRMP2 (collapsin response mediator protein 2) is involved in proper dendritic field organization. J Neurosci. (2012) 32:1360-5. doi: 10.1523/JNEUROSCI.5563-11.2012

176. Yamashita N, Takahashi A, Takao K, Yamamoto T, Kolattukudy $\mathrm{P}$, Miyakawa $\mathrm{T}$, et al. Mice lacking collapsin response mediator protein 1 manifest hyperactivity, impaired learning and memory, and impaired prepulse inhibition. Front Behav Neurosci. (2013) 7:216. doi: $10.3389 /$ fnbeh.2013.00216
177. Zhang H, Kang E, Wang Y, Yang C, Yu H, Wang Q, et al. Brainspecific Crmp2 deletion leads to neuronal development deficits and behavioural impairments in mice. Nat Commun. (2016) 7:11773. doi: $10.1038 /$ ncomms 11773

178. Nakamura H, Takahashi-Jitsuki A, Makihara H, Asano T, Kimura Y, Nakabayashi J, et al. Proteome and behavioral alterations in phosphorylationdeficient mutant Collapsin Response Mediator Protein2 knock-in mice. Neurochem Int. (2018) 119:207-17. doi: 10.1016/j.neuint.2018. 04.009

179. Quach TT, Honnorat J, Kolattukudy PE, Khanna R, Duchemin AM. CRMPs: critical molecules for neurite morphogenesis and neuropsychiatric diseases. Mol Psychiatry. (2015) 20:1037-45. doi: 10.1038/mp.2015.77

180. Johnson BD, Schumacher RJ, Ross ED, Toft DO. Hop modulates Hsp70/Hsp90 interactions in protein folding. J Biol Chem. (1998) 273:367986. doi: $10.1074 /$ jbc. 273.6 .3679

181. Longshaw VM, Chapple JP, Balda MS, Cheetham ME, Blatch GL. Nuclear translocation of the Hsp70/Hsp90 organizing protein $\mathrm{mSTI1}$ is regulated by cell cycle kinases. J Cell Sci. (2004) 117(Pt 5):701-10. doi: 10.1242/jcs. 00905

182. Hajj GN, Arantes CP, Dias MV, Roffe M, Costa-Silva B, Lopes MH, et al. The unconventional secretion of stress-inducible protein 1 by a heterogeneous population of extracellular vesicles. Cell Mol Life Sci. (2013) 70:3211-27. doi: 10.1007/s00018-013-1328-y

183. Zanata SM, Lopes MH, Mercadante AF, Hajj GN, Chiarini LB, Nomizo $\mathrm{R}$, et al. Stress-inducible protein 1 is a cell surface ligand for cellular prion that triggers neuroprotection. EMBO J. (2002) 21:3307-16. doi: 10.1093/emboj/cdf325

184. Lopes MH, Hajj GN, Muras AG, Mancini GL, Castro RM, Ribeiro KC, et al. Interaction of cellular prion and stress-inducible protein 1 promotes neuritogenesis and neuroprotection by distinct signaling pathways. $J$ Neurosci. (2005) 25:11330-9. doi: 10.1523/JNEUROSCI.2313-05.2005

185. Beraldo FH, Arantes CP, Santos TG, Queiroz NG, Young K, Rylett RJ, et al. Role of alpha7 nicotinic acetylcholine receptor in calcium signaling induced by prion protein interaction with stress-inducible protein 1. J Biol Chem. (2010) 285:36542-50. doi: 10.1074/jbc.M110.157263

186. Tokuda K, Kuramitsu Y, Byron B, Kitagawa T, Tokuda N, Kobayashi D, et al. Up-regulation of DRP-3 long isoform during the induction of neural progenitor cells by glutamate treatment in the ex vivo rat retina. Biochem Biophys Res Commun. (2015) 463:593-9. doi: 10.1016/j.bbrc.2015.05.102

187. Beraldo FH, Thomas A, Kolisnyk B, Hirata PH, De Jaeger X, Martyn AC, et al. Hyperactivity and attention deficits in mice with decreased levels of stressinducible phosphoprotein 1 (STIP1). Dis Model Mech. (2015) 8:1457-66. doi: $10.1242 / \mathrm{dmm} .022525$

188. Saint-Martin M, Joubert B, Pellier-Monnin V, Pascual O, Noraz N, Honnorat J. Contactin-associated protein-like 2, a protein of the neurexin family involved in several human diseases. Eur J Neurosci. (2018) 48:1906-23. doi: 10.1111/ejn.14081

189. Poliak S, Gollan L, Martinez R, Custer A, Einheber S, Salzer JL, et al. Caspr2, a new member of the neurexin superfamily, is localized at the juxtaparanodes of myelinated axons and associates with $\mathrm{K}+$ channels. Neuron. (1999) 24:1037-47. doi: 10.1016/S0896-6273(00) 81049-1

190. Abrahams BS, Tentler D, Perederiy JV, Oldham MC, Coppola G, Geschwind DH. Genome-wide analyses of human perisylvian cerebral cortical patterning. Proc Natl Acad Sci USA. (2007) 104:17849-54. doi: 10.1073/pnas.0706128104

191. Gordon A, Salomon D, Barak N, Pen Y, Tsoory M, Kimchi T, et al. Expression of Cntnap2 (Caspr2) in multiple levels of sensory systems. Mol Cell Neurosci. (2016) 70:42-53. doi: 10.1016/j.mcn.2015. 11.012

192. Ogawa Y, Horresh I, Trimmer JS, Bredt DS, Peles E, Rasband MN. Postsynaptic density-93 clusters Kv1 channels at axon initial segments independently of Caspr2. J Neurosci. (2008) 28:5731-9. doi: 10.1523/JNEUROSCI.4431-07.2008

193. Zou Y, Zhang WF, Liu HY, Li X, Zhang X, Ma XF, et al. Structure and function of the contactin-associated protein family in myelinated axons and their relationship with nerve diseases. Neural Regen Res. (2017) 12:1551-8. doi: $10.4103 / 1673-5374.215268$ 
194. Gdalyahu A, Lazaro M, Penagarikano O, Golshani P, Trachtenberg JT, Geschwind DH. The autism related protein Contactin-Associated ProteinLike 2 (CNTNAP2) stabilizes new spines: an in vivo mouse study. PLoS ONE. (2015) 10:e0125633. doi: 10.1371/journal.pone.0125633

195. Poot M. Connecting the CNTNAP2 Networks with neurodevelopmental disorders. Mol Syndromol. (2015) 6:7-22. doi: 10.1159/0003 71594

196. Penagarikano O, Abrahams BS, Herman EI, Winden KD, Gdalyahu A, Dong $\mathrm{H}$, et al. Absence of CNTNAP2 leads to epilepsy, neuronal migration abnormalities, and core autism-related deficits. Cell. (2011) 147:235-46. doi: 10.1016/j.cell.2011.08.040

197. van Sonderen A, Arino H, Petit-Pedrol M, Leypoldt F, Kortvelyessy P, Wandinger KP, et al. The clinical spectrum of Caspr2 antibody-associated disease. Neurology. (2016) 87:521-8. doi: 10.1212/WNL.0000000000002917

198. Patterson KR, Dalmau J, Lancaster E. Mechanisms of Caspr2 antibodies in autoimmune encephalitis and neuromyotonia. Ann Neurol. (2018) 83:40-51. doi: 10.1002/ana.25120

199. van Sonderen A, Petit-Pedrol M, Dalmau J, Titulaer MJ. The value of LGI1, Caspr2 and voltage-gated potassium channel antibodies in encephalitis. Nat Rev Neurol. (2017) 13:290-301. doi: 10.1038/nrneurol.2017.43

200. Fernandes D, Santos SD, Coutinho E, Whitt JL, Beltrao N, Rondao T, et al. Disrupted AMPA receptor function upon genetic- or antibodymediated loss of autism-associated CASPR2. Cereb Cortex. (2019) bhz032. doi: $10.1093 /$ cercor/bhz032
201. Dawes JM, Weir GA, Middleton SJ, Patel R, Chisholm KI, Pettingill P, et al. Immune or genetic-mediated disruption of CASPR2 causes pain hypersensitivity due to enhanced primary afferent excitability. Neuron. (2018) 97:806-22 e10. doi: 10.1016/j.neuron.2018.01.033

202. Brimberg L, Mader S, Jeganathan V, Berlin R, Coleman TR, Gregersen PK, et al. Caspr2-reactive antibody cloned from a mother of an ASD child mediates an ASD-like phenotype in mice. Mol Psychiatry. (2016) 21:1663-71. doi: $10.1038 / \mathrm{mp} .2016 .165$

203. Coutinho E, Menassa DA, Jacobson L, West SJ, Domingos J, Moloney TC, et al. Persistent microglial activation and synaptic loss with behavioral abnormalities in mouse offspring exposed to CASPR2-antibodies in utero. Acta Neuropathol. (2017) 134:567-83. doi: 10.1007/s00401-017-1751-5

Conflict of Interest Statement: The authors declare that the research was conducted in the absence of any commercial or financial relationships that could be construed as a potential conflict of interest.

Copyright (C) 2019 Mazón-Cabrera, Vandormael and Somers. This is an open-access article distributed under the terms of the Creative Commons Attribution License (CC $B Y)$. The use, distribution or reproduction in other forums is permitted, provided the original author(s) and the copyright owner(s) are credited and that the original publication in this journal is cited, in accordance with accepted academic practice. No use, distribution or reproduction is permitted which does not comply with these terms. 